\title{
Some Factors That Influence Seasonal Precipitation in Argentinean Chaco
}

\author{
Marcela Hebe González, ${ }^{1,2}$ María Laura Cariaga, ${ }^{1}$ and María de los Milagros Skansi ${ }^{3}$ \\ ${ }^{1}$ Department of Atmospheric and Oceanic Science, FCEN, University of Buenos Aires, Buenos Aires, 2 piso, Pabellón II, \\ Ciudad Universitaria, 1428 Buenos Aires, Argentina \\ ${ }^{2}$ Research Center of Ocean and Atmosphere, CONICET/UBA and UMI-IFAECI/CNRS, 2 piso, Pabellón II, \\ Ciudad Universitaria, 1428 Buenos Aires, Argentina \\ ${ }^{3}$ National Meteorological Service of Argentina, 25 de Mayo 658, Buenos Aires, Argentina
}

Correspondence should be addressed to Marcela Hebe González, gonzalez@cima.fcen.uba.ar

Received 28 March 2012; Revised 6 July 2012; Accepted 24 July 2012

Academic Editor: Soon-Il An

Copyright (C) 2012 Marcela Hebe González et al. This is an open access article distributed under the Creative Commons Attribution License, which permits unrestricted use, distribution, and reproduction in any medium, provided the original work is properly cited.

\begin{abstract}
The Chaco plain region in Argentina is located in the north of the country and east of Los Andes where the main activity is the agriculture. As such activity is highly affected by interannual rainfall variability, the influence of some of the principal atmospheric and oceanic forcing is investigated in this paper. Results show that the factors which affect precipitation highly depend on the season and the subregion. The position of the South Atlantic Height and the sea surface temperature in the coast of southern Brazil and Buenos Aires seem to be the factors that affect rainfall, all over the year. The El Niño-Southern Oscillation phenomenon affects summer and spring rainfall and the Southern Annular Mode involves spring precipitation but both only in the east of the study region. Furthermore, enhanced convection in Central Brazil, mainly influences autumn and spring rainfall.
\end{abstract}

\section{Introduction}

First of all, a description of the climate and relevant economic activities in the study area is detailed. Chaco plain region is located in the north of Argentina, eastward the Andes Mountain Range. This area comprises the ecosystems of dry Chaco in the west, wet Chaco in the east, and forest yungas, which are discontinuously scattered in Salta, Jujuy, and Tucumán provinces (Figure 1). The climate is subtropical with a mean annual rainfall cycle showing a minimum in winter, which is more pronounced in the west, with wet conditions prevailing from October to April [1$3]$. The Andes chain lies along the west of Argentina and prevents the access of humidity from the Pacific Ocean north of $38^{\circ} \mathrm{S}$, where the mountains are high. Therefore, winds prevail from the north and the east because the flow is governed by two factors: the South Atlantic Height and an intermittent thermal low-pressure system that is located between $20^{\circ}$ and $30^{\circ} \mathrm{S}$, in northwest Argentina, east of the Andes. This system is observed all year long, but it is deeper in summer than in winter [4]. When this low is present, northerly flow is favored at low levels over the subtropical region. The easterly low-level flow at low latitudes is channeled towards the south between the Bolivian Plateau and the Brazilian Planalto, advecting warm and humid air to southern Brazil, Paraguay, Uruguay, and subtropical Argentina and depicting a typical feature that many authors have studied [5-8]. Besides, intermittent eruptions of polar fronts from the south modify this scheme, causing a west or a southwest flow in low levels after the frontal passage.

In the east area of this region, there are performed great agricultural activities that have expanded to the west in the subwet plains during the last century because of the extension of the agricultural border westwards [9]. However, there is some evidence that these trends could be reversing $[3,10]$ in some locations, and this is the major disadvantage for the agricultural activity nowadays.

The great interconnection between agricultural activity and interannual rainfall variability makes it necessary to 


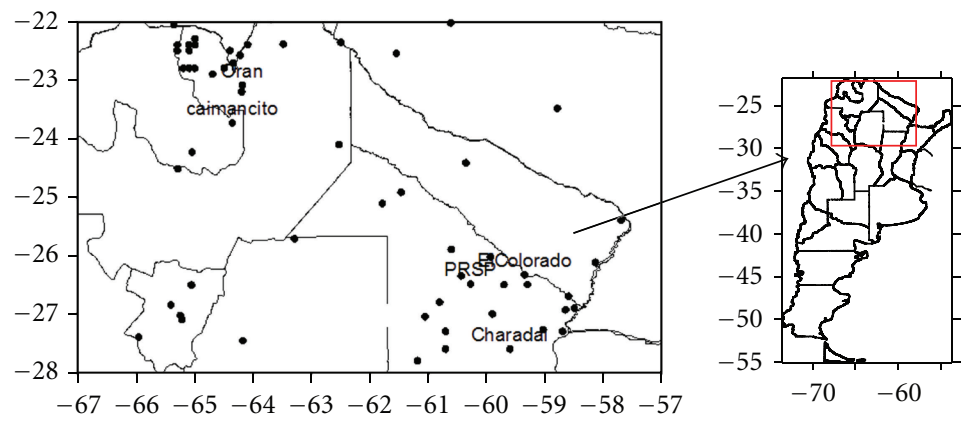

Figure 1: Stations used in the study. Stations refered to in Result section are detailed.

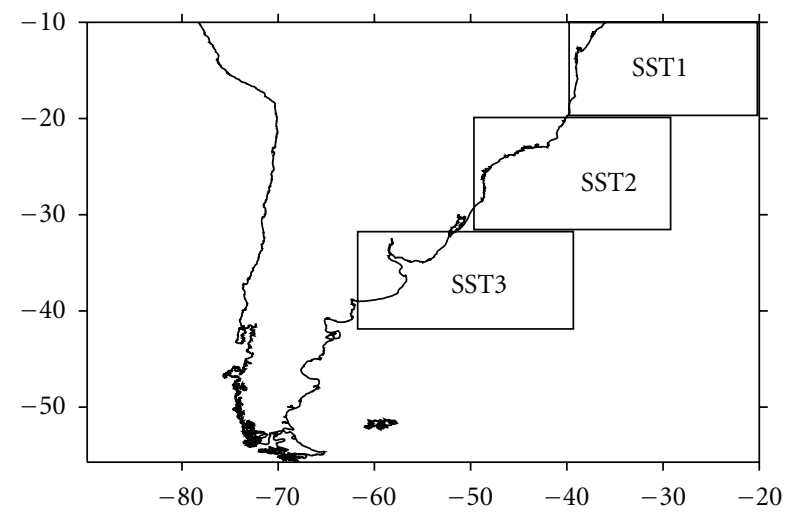

FIGURE 2: Areas where SST indexes are defined.

TABle 1: Index anomalies for Spring 1999 and 1994. Anomalies are computed from 1961-2010 seasonal mean.

\begin{tabular}{lcc}
\hline Index & SON 1999 & SON 1994 \\
\hline ENSO & $-1.2^{\circ} \mathrm{C}$ & $0.9^{\circ} \mathrm{C}$ \\
SST1 & $-0.22^{\circ} \mathrm{C}$ & $-0.08^{\circ} \mathrm{C}$ \\
SST2 & $-0.65^{\circ} \mathrm{C}$ & $0.23^{\circ} \mathrm{C}$ \\
SST3 & $-0.3^{\circ} \mathrm{C}$ & $0.09^{\circ} \mathrm{C}$ \\
OLR & $1.53 \mathrm{w} / \mathrm{m}^{2}$ & $-17.41 \mathrm{w} / \mathrm{m}^{2}$ \\
LATA & $-0.83^{\circ}$ & 0 \\
LONA & $1.53^{\circ}$ & $-5.97^{\circ}$ \\
IA & $3.59 \mathrm{~m}$ & $-4.49 \mathrm{~m}$ \\
AAO & 2.37 & -0.98 \\
DMI & $-0.18^{\circ} \mathrm{C}$ & $2.34^{\circ} \mathrm{C}$ \\
\hline
\end{tabular}

understand the large circulation patterns associated with precipitation. It is know that slow variations in the earth's boundary conditions (i.e., sea surface temperature) can influence global atmospheric circulation and thus, precipitation. Therefore, some large-scale atmospheric forcing will be described and then their influence on seasonal Chaco Argentinean rainfall will be investigated.

In the following paragraphs the main forcing of interannual rainfall variability will be detailed. First, those ones related to SST anomalies in tropical oceans, like the Southern Oscillation and the Indian Dipole, are addressed. Then, other factors related to hemispherical circulation patterns, like the Southern Annular Mode, or related to regional patterns, like the effect of the Southern Atlantic Height and the Southern American Monsoon, are described.

Some regions with significant sea surface temperature (SST) anomaly can act as a remote forcing generating teleconnections. Indeed, the most relevant SST pattern in the Pacific Ocean is the El Niño-Southern Oscillation (ENSO). The SST anomalies in tropical Pacific generate a Rossby wave trend which propagates meridionally towards middlelatitudes from the tropical source [11-13]. This pattern, called the "Pacific South American Pattern", is described by Mo (2000) [12] when depicting South Hemisphere climate. Some authors [14-16] have studied the relation between greater than normal rainfall and "El Niño" events in northeastern Argentina. Another oscillation, related to SST anomalies in the Indian Ocean, is called "Indian Ocean Dipole" (DMI) [17]. A positive DMI period is characterized by cooler than normal water in the tropical eastern Indian Ocean and warmer than normal water in the tropical western Indian Ocean, and it has been associated with a decrease of rainfall in central and southern Australia. Chan et al. [18] showed that DMI causes a dipolar pattern in rainfall anomalies between subtropical La Plata basin and central Brazil where rainfall is reduced (enhanced) over latter (former) during austral spring. It is also associated with a Rossby wave trend extending from the subtropical south Indian Ocean to the subtropical South Atlantic. Liu et al. [19] found evidence for this teleconnection using the theory of planetary waves [20] and showed that the energy propagation path of planetary waves is approximately along the path of Rossby wave train, a possible dynamic explanation for such teleconnection pattern.

The Antarctic Oscillation is an annular-like pattern called "Southern Annular Mode" (SAM) [21] and its positive phase is defined by negative pressure anomalies at high latitudes combined with wave-like pattern at middle latitudes. This feature increases zonal winds at high latitudes, decreases heat exchange between poles and mid latitudes, and so modifies storm tracks. Previous papers have shown SAM influence on rainfall variability in some regions of South America. For example, Silvestri and Vera [22] found significant relation between them in southeastern South America particularly during November and December; Reboita et al. [23] detected 


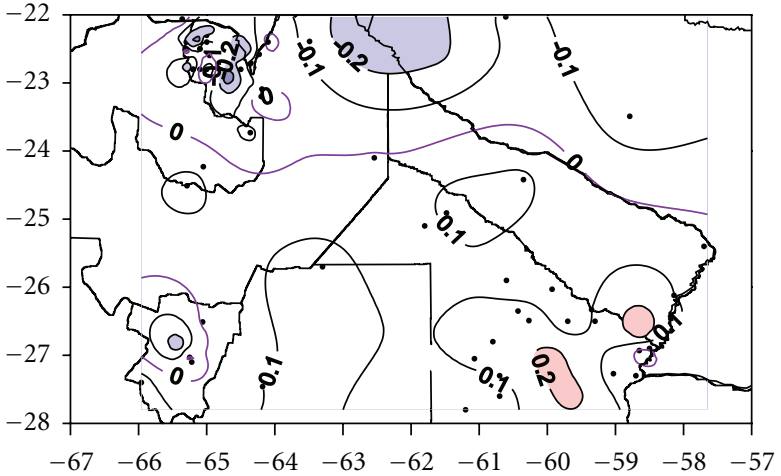

(a) AAO

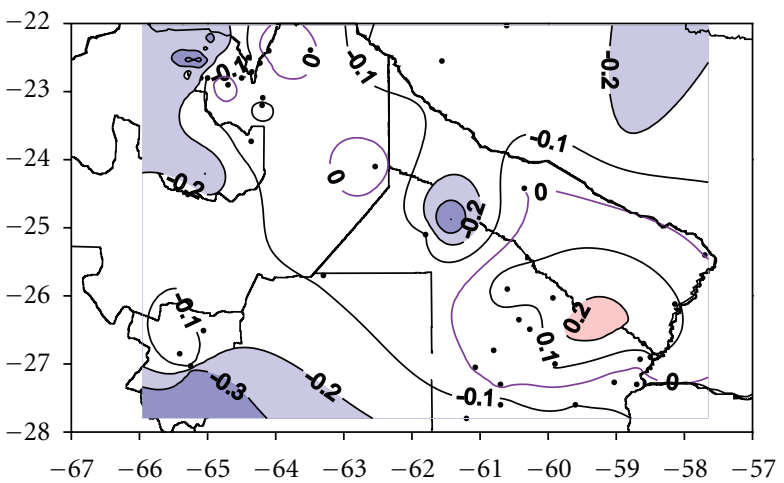

(c) OLR

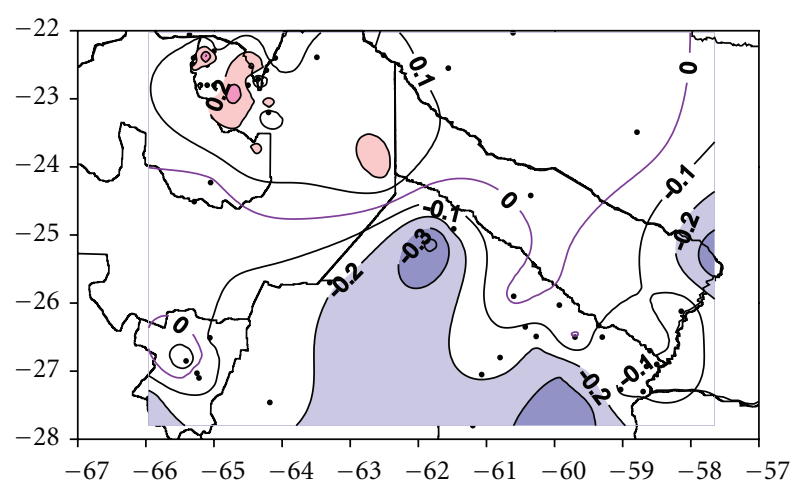

(e) LATA

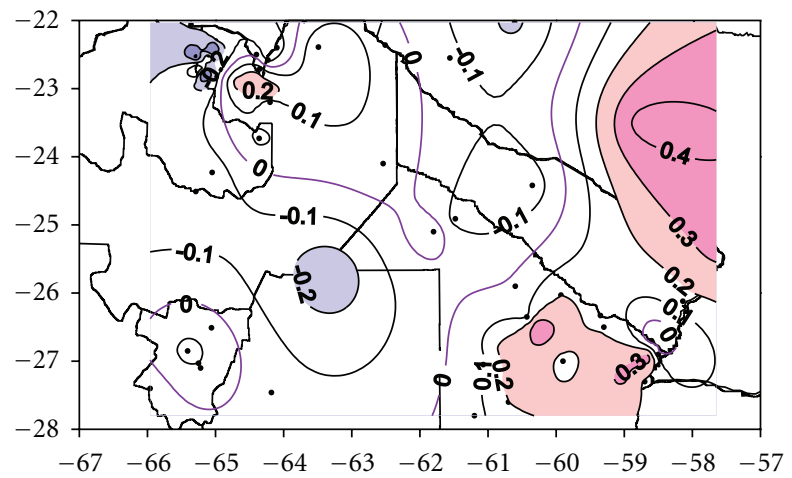

(g) ENSO

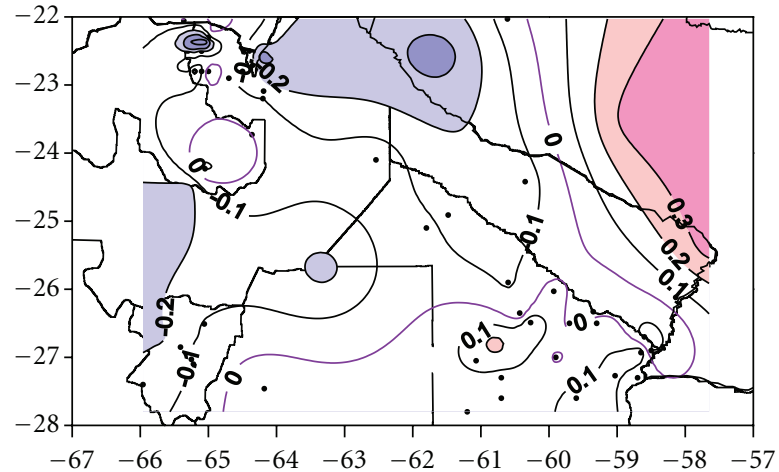

(b) DMI

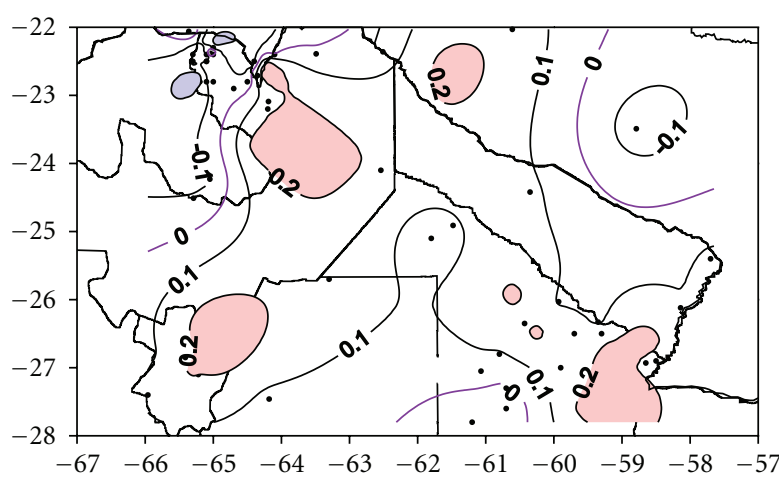

(d) IA

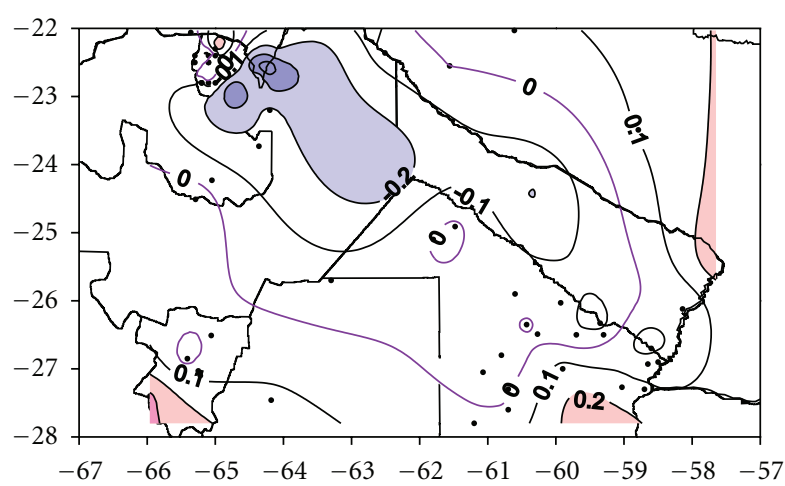

(f) LONA

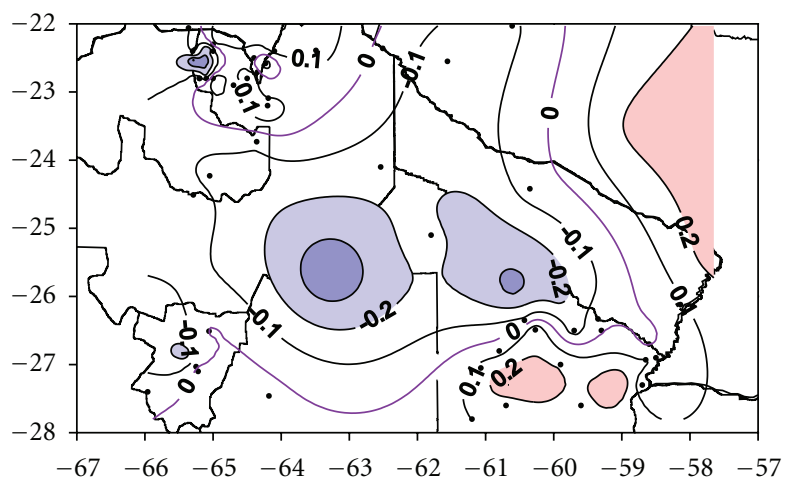

(h) SST1

Figure 3: Continued. 


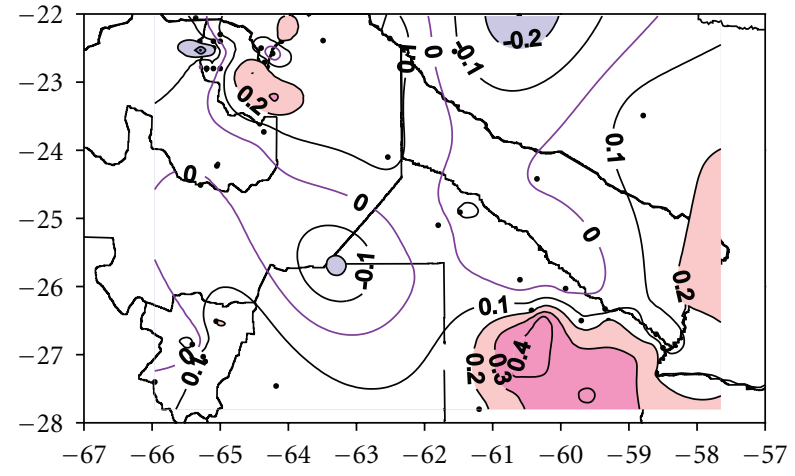

(i) SST2

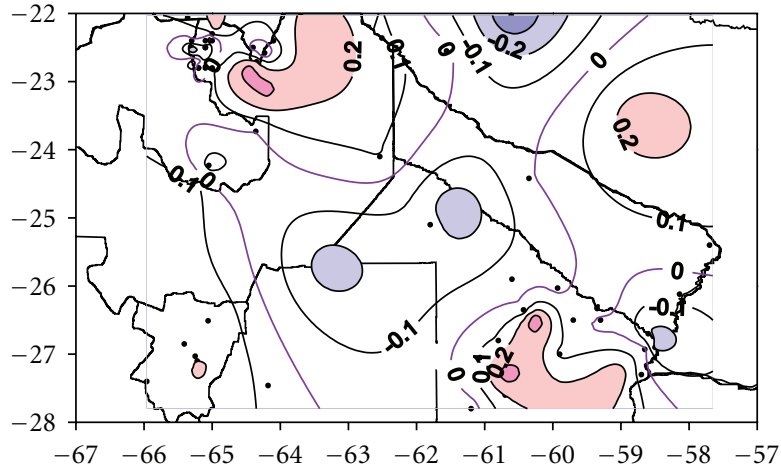

(j) SST3

Figure 3: Correlation between summer (DJF) rainfall and indexes defined in the text. Areas shaded blue and red (light blue and pink) are significant at the $95 \%(90 \%)$ confidence level and represent negative (positive) correlations.

a decrease of frontal activity when positive phase of SAM is present. In other regions of the Southern Hemisphere some authors have detected some relations between rainfall and SAM, too. For example, Zheng and Frederiksen [24] showed that this signal affects summer rainfall variability in the New Zealand sector, and Reason and Rouault [25] showed that wetter (drier) winters in western South Africa occur during the negative (positive) SAM phase.

Another factor that influences precipitation in subtropical Argentina is the annual displacement of the Intertropical Convergence Zone (ITCZ) over South America. A poleward extension of the summer convection in the tropical Americas has been detected, including large-scale land-sea temperature contrast, a large-scale thermally direct circulation with a continental rising branch and an oceanic sinking branch, surface low pressure, an upper level anticyclone, intense lowlevel inflow of moisture to the continent, and associated seasonal changes in precipitation. This phenomenon is called the "South American Monsoon System" [26]. This displacement generates a rainy season in central Brazil in austral summer and causes the entrance of humid air from the north towards subtropical Argentina. The interannual variability of such displacement influences summer, autumn, and spring precipitation in a vast region of South America. Gonzalez and Barros [29, 31] explored the relation between the interannual variability of the austral South American monsoon onset date and the interannual variability of spring rainfall in subtropical South America. They found that an early (delayed) onset is associated with decreased (enhanced) rainfall only in southern Brazil, while in Argentina and Uruguay the signal is opposite.

The combined effect of the position and intensity of the South Atlantic Height (SAH) and the Atlantic SST in the surrounding of the continent is another forcing to precipitation. In fact, when SST is high, the evaporation is enhanced and the incoming of wet air into the continent through the SAH can be intensified, reinforcing rainfall in the northeast of the study region. Doyle and Barros [27] studied the relation between SST in the Atlantic Ocean and rainfall in southern South America using canonical correlation, and they found that this influence is great in northeastern Argentina and southern Brazil.

The objective of this paper is to detect the possible circulation patterns that influence seasonal precipitation in the Chaco region of Argentina using rainfall measurements from different sources. This paper is organized as follows: Section 2 describes the dataset and the methodology; Section 3 presents the results; Section 4 shows a case of study; Section 5 the main conclusions.

\section{Data and Methodology}

Monthly rainfall data in 60 stations (57 in Argentina and 3 in Paraguay) are derived from different sources: The Meteorology and Hydrology Direction of Paraguay (DMH), the National Meteorological Service (SMN) of Argentina, the Secretary of Hydrology of Argentina (SRH), the Regional Commission of Bermejo River (COREBE), and the Provincial Water Administration of Chaco (APA). The area of study is located between $22^{\circ} \mathrm{S}$ and $28^{\circ} \mathrm{S}$ and between $66^{\circ} \mathrm{W}$ and $58^{\circ} \mathrm{W}$, including the Argentinean provinces of Chaco, Formosa, Tucumán, east of Salta and Jujuy, north of Santiago del Estero, and Santa Fe and the Paraguayan Chaco (Figure 1). Stations data records are 1960-2010 and their quality has been carefully proved. Some techniques were applied with that purpose. First we discriminated cases with no precipitation in one month from missing data, especially in the northwest of Argentina in winter, when rainfall is scarce. All the selected stations have less than $20 \%$ of missing monthly rainfall data, and no stations have records affected by changes of location and instrumentation. Rainfall greater that percentile 95 was controlled in order to detect outliers. In a consistency check, the observation was compared with a near station value to see if it was physically or climatologically consistent. Suspicious observations according to inconsistencies were not considered. Kriging interpolation is used to draw the spatial correlation fields. It is a geostatistical gridding method that produces visually appealing maps from irregularly spaced data. It is a spatial interpolation method which gives the best linear unbiased predictors of the 


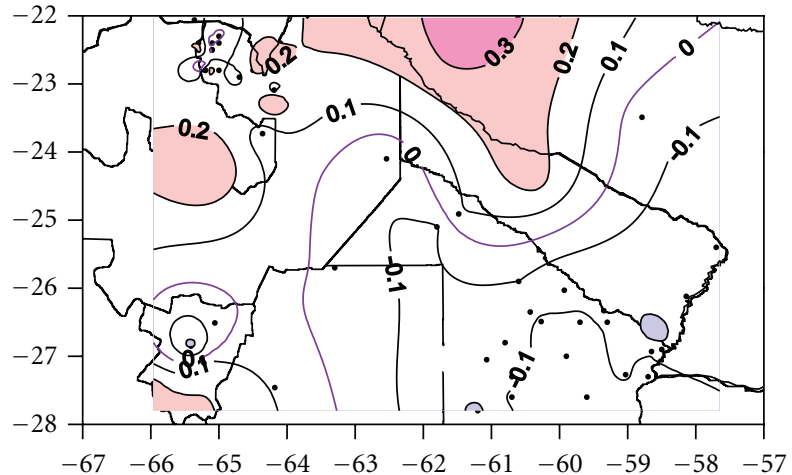

(a) $\mathrm{AAO}$

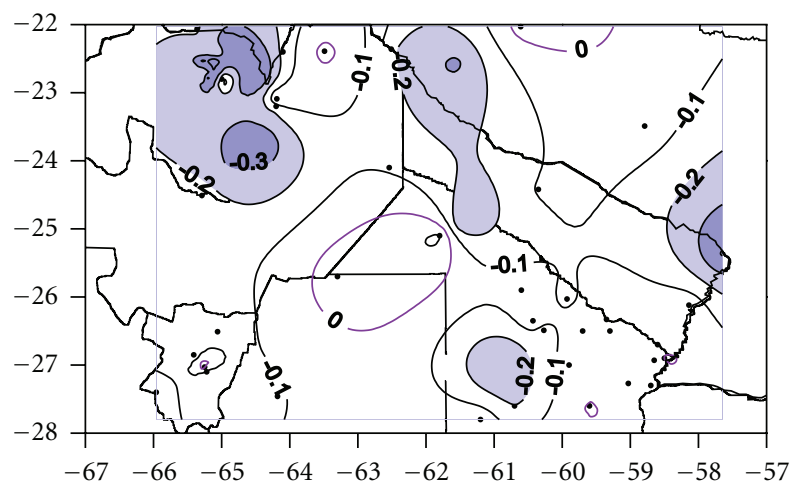

(c) OLR

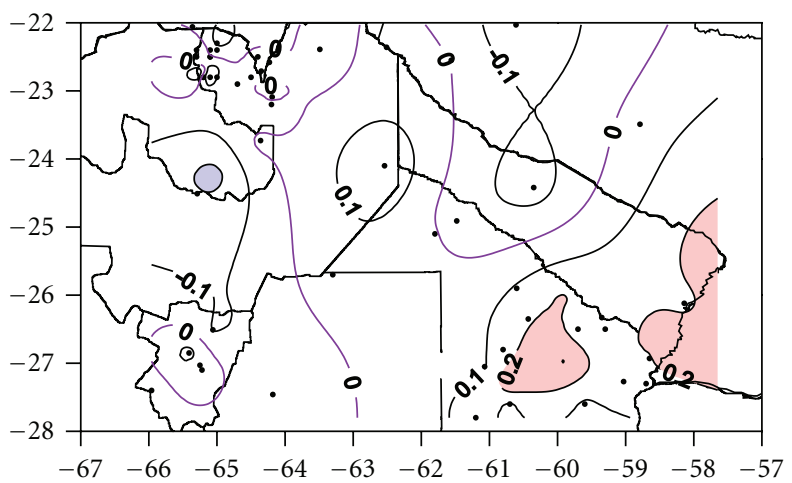

(e) LATA

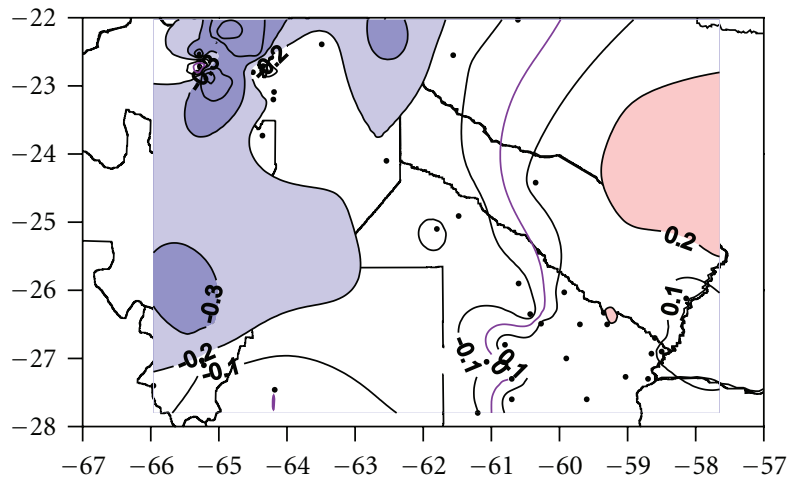

(g) ENSO

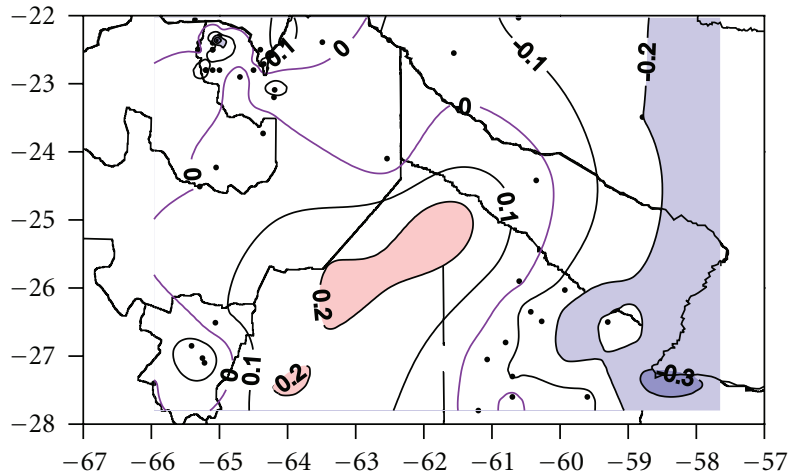

(b) DMI

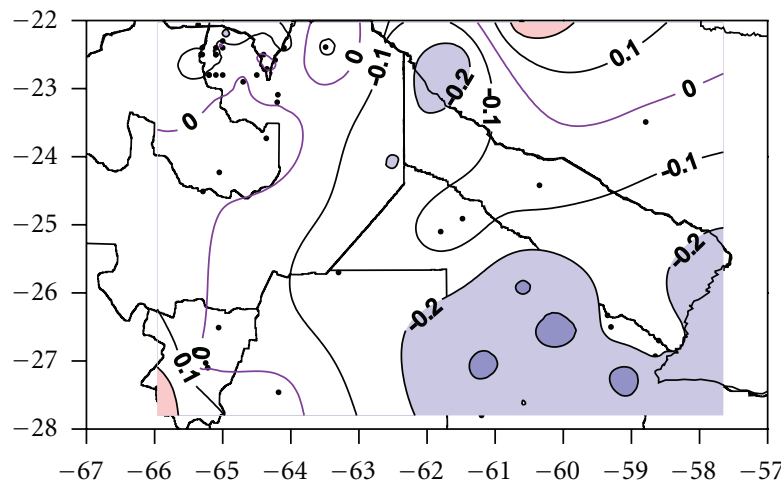

(d) IA

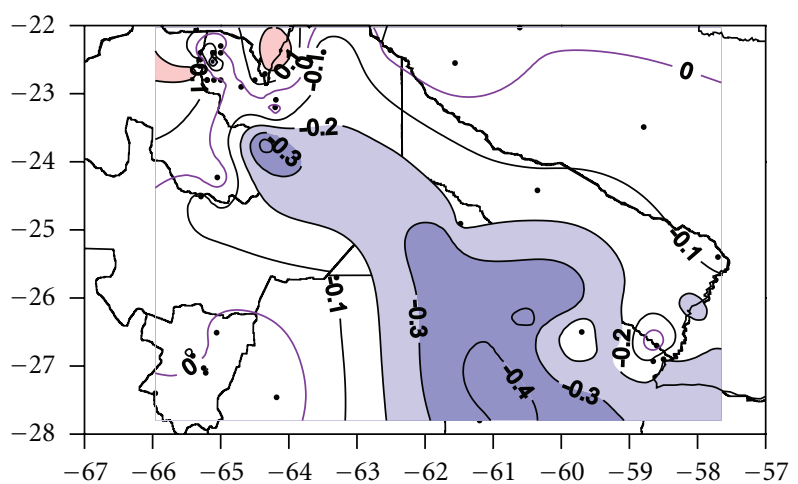

(f) LONA

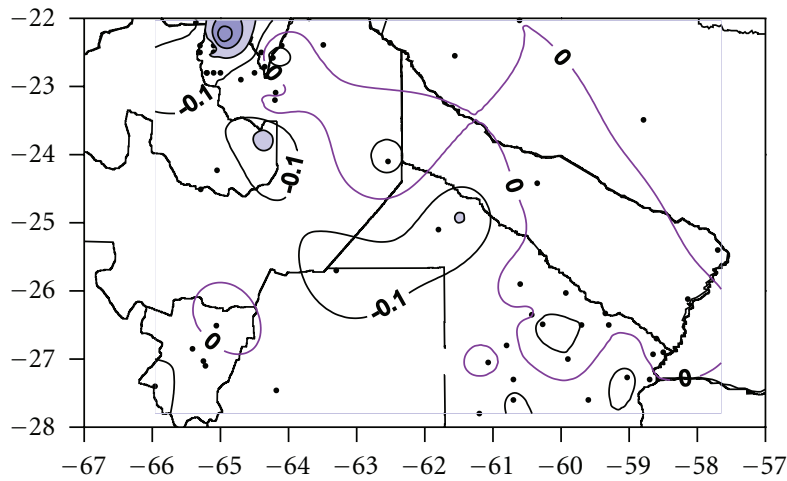

(h) SST1

FIgURe 4: Continued. 


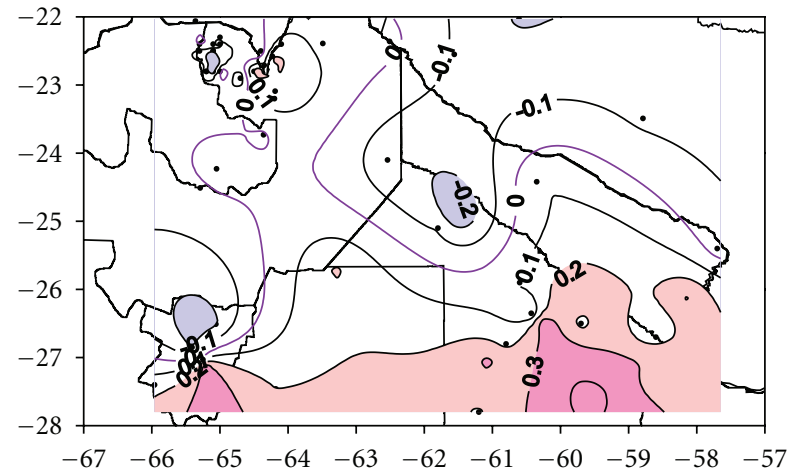

(i) SST2

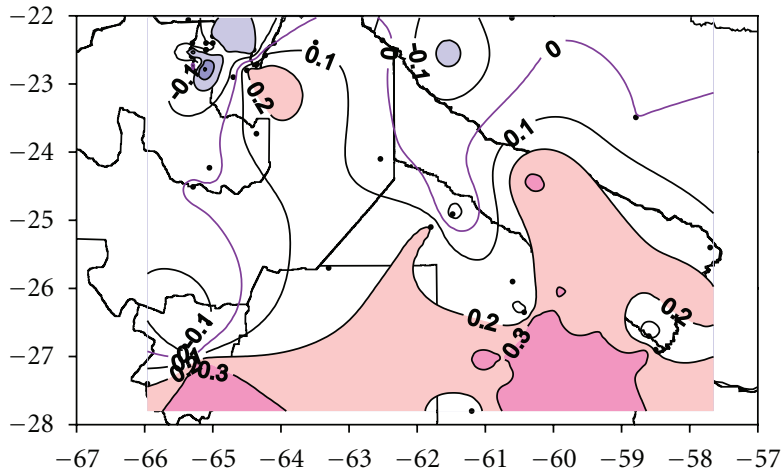

(j) SST3

FIgURE 4: Idem Figure 3 for Autumn (MAM) rainfall.

unobserved values and provides an estimate of the prediction error variance. The unobserved value is calculated with the help of some nearest observed values within a given radius from the station. Kriging is based on the assumption that the parameter being interpolated can be treated as a regionalized variable. A regionalized variable is intermediate between a truly random variable and a completely deterministic variable and it varies in a continuous manner from one location to the next and therefore points that are near each other have a certain degree of spatial correlation, but points that are widely separated are statistically independent. Kriging is a set of linear regression routines which minimize estimation variance from a predefined covariance model.

Seasonal rainfall is calculated as the accumulated precipitation during 3 months: summer (December-JanuaryFebruary, DJF), autumn (March-April-May, MAM), winter (June-July-August, JJA), spring (September-OctoberNovember, SON), and annual total (from January to December).

Some indexes are used in order to analyze the relation between seasonal rainfall and the different forcing described in the introduction. Such indexes will be described below.

El Niño-Southern Oscillation effect is evaluated using the mean SST in the EN3.4. region (ENSO), obtained from Climate Prediction Center (CPC) webpage from National Oceanic and Atmospheric Administration (NOAA).

The SAM pattern is represented quantitatively by an index (AAO), defined as the difference in the normalized monthly zonal mean sea level pressure between $40^{\circ} \mathrm{S}$ and $70^{\circ} \mathrm{S}[28]$. This index was obtained from http://ljp.lasg.ac.cn/ dct/page/65572.

The DMI is commonly measured by an index defined as the difference between SST in the western $\left(50^{\circ} \mathrm{E}\right.$ to $70^{\circ} \mathrm{E}$ and $10^{\circ} \mathrm{S}$ to $\left.10^{\circ} \mathrm{N}\right)$ and eastern $\left(90^{\circ} \mathrm{E}\right.$ to $110^{\circ} \mathrm{E}$ and $10^{\circ} \mathrm{S}$ to $0^{\circ} \mathrm{S}$ ) equatorial Indian Ocean. The index is called the Dipole Mode Index (DMI) [17]. Data were obtained from SST DMI dataset derived from HadlSST dataset (http:// www.jamstec.go.jp/frcgc/research/d1/iod/DATA/dmi_HadISST.txt).
Mean outgoing longwave radiation between $5^{\circ} \mathrm{S}$ to $15^{\circ} \mathrm{S}$ and $65^{\circ} \mathrm{W}$ to $45^{\circ} \mathrm{W}$ (OLR), in Central Brazilian forest, is used to identify convection associated with the displacement of the ITCZ over South America. This area is selected using the results obtained by Gonzalez and Barros [29]. They used a principal component analysis of monthly mean outgoing longwave radiation and detected an area of maximum variability associated with the displacement of ITCZ. Mean OLR data in the selected area were obtained from National Center of Environmental Prediction (NCEP) reanalysis [30].

To analyze the influence of the Atlantic SST near the continent, three indexes are defined: mean SST in $10^{\circ} \mathrm{S}$ to $20^{\circ} \mathrm{S}$ and $40^{\circ} \mathrm{W}$ to $25^{\circ} \mathrm{W}$ (SST1), mean SST in $20^{\circ} \mathrm{S}$ to $30^{\circ} \mathrm{S}$, and $50^{\circ} \mathrm{W}$ to $30^{\circ} \mathrm{W}$ (SST2), both in Brazilian coast and mean SST in $30^{\circ} \mathrm{S}$ to $40^{\circ} \mathrm{S}$ and $65^{\circ} \mathrm{W}$ to $40^{\circ} \mathrm{W}$ (SST3) in the coast of Argentina and Uruguay (Figure 2). They are defined using Doyle and Barros [27] and data were obtained from NCEP reanalysis.

Data from NCEP reanalysis [30] are used to calculate the intensity (IA), latitude (LATA), and longitude (LONA) of the SAH maximum. IA is defined as the maximum value of $1000 \mathrm{Hpa}$ geopotential height field in $\left(0^{\circ}\right.$ to $40^{\circ} \mathrm{S}$ and $40^{\circ} \mathrm{W}$ to $10^{\circ} \mathrm{E}$ ) in the South Atlantic Ocean. LATA and LONA are the coordinates of the location of such maximum. An algorithm was constructed to detect such maximum.

Simultaneous correlations between seasonal (DJF, MAM, JJA, and SON) and annual rainfall in the 60 stations and indexes defined below (ENSO, AAO, DMI, OLR, IA, LATA, LONA, SST1, SST2, and SST3) are calculated. Correlations greater than $0,27(0,2)$ are significant at $95 \%(90 \%)$ confidence level, using a $t$-test. The results allow describing some relations between the seasonal rainfall and circulation forcing.

In order to support the results derived by the correlations fields, some stations (Figure 1) are considered to show the combined influence of more than one factor over seasonal rainfall. In fact, some multiple linear regressions are constructed using a standard methodology (significant at the $95 \%$ confidence level). The rainfall variance explained by all the factors is detailed. 


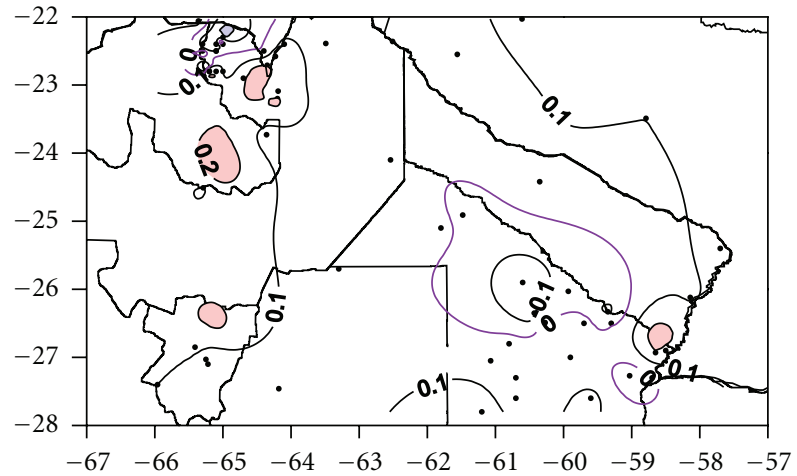

(a) $\mathrm{AAO}$

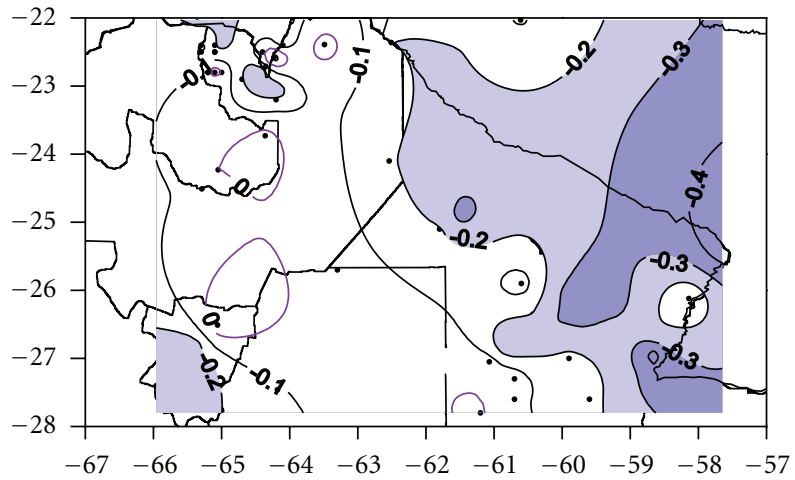

(c) OLR

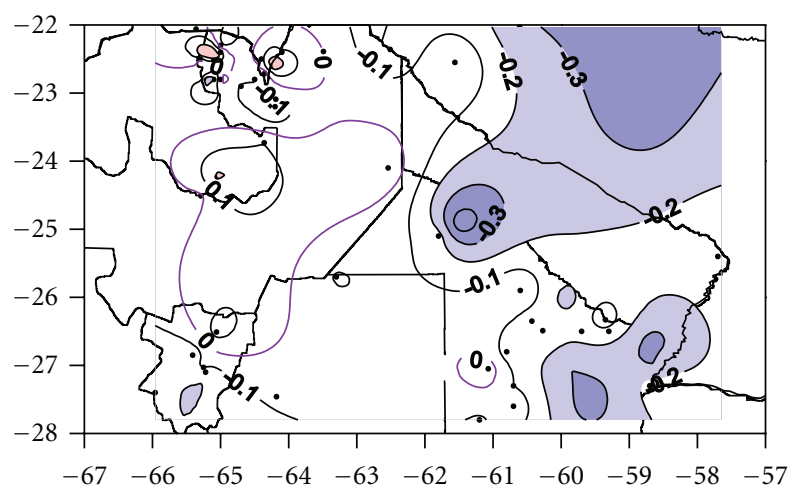

(e) LATA

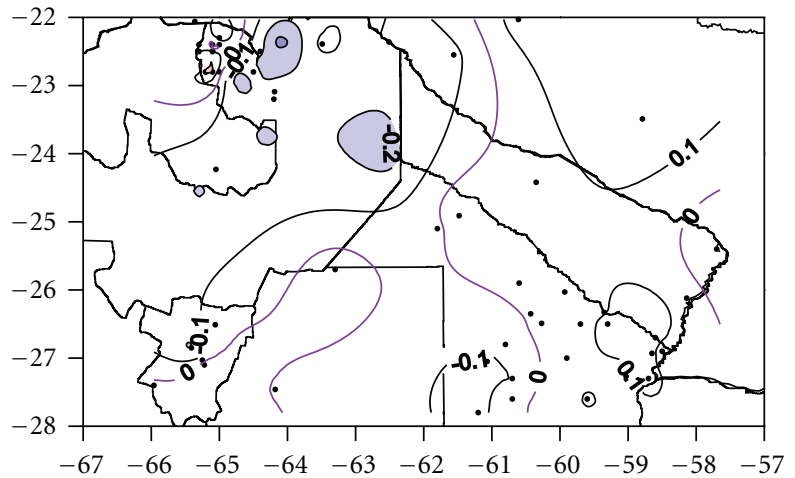

(g) ENSO

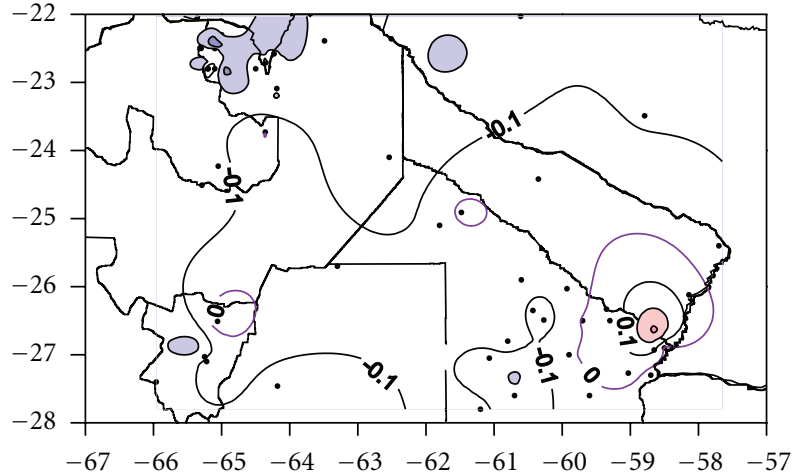

(b) DMI

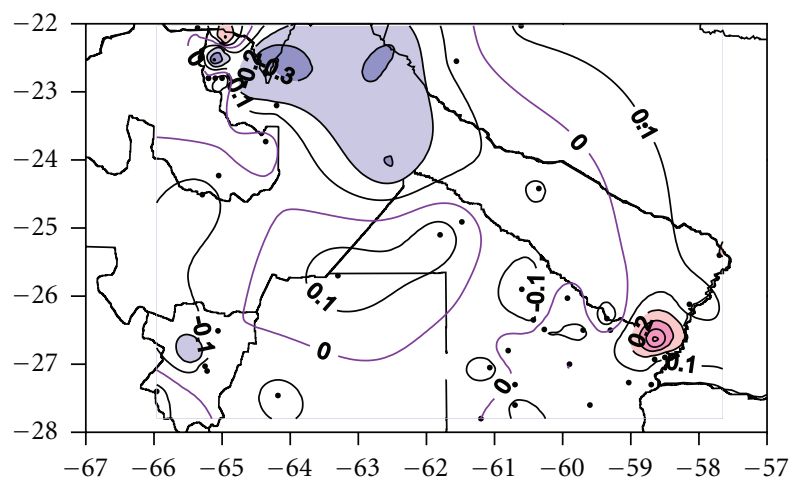

(d) IA

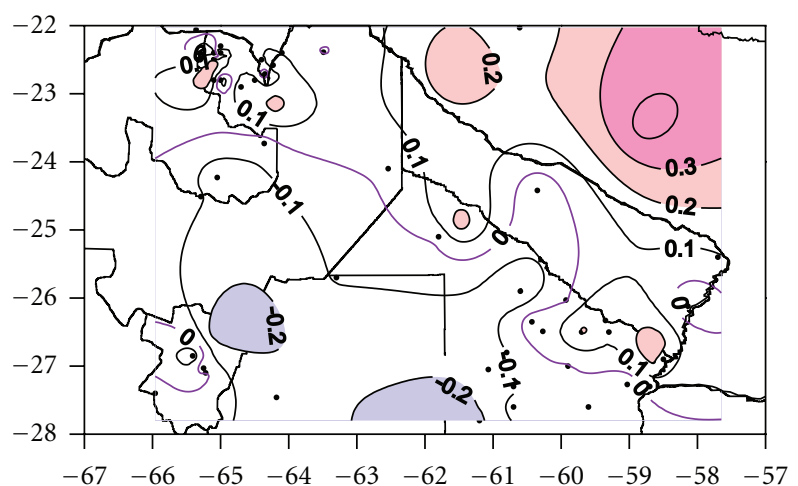

(f) LONA

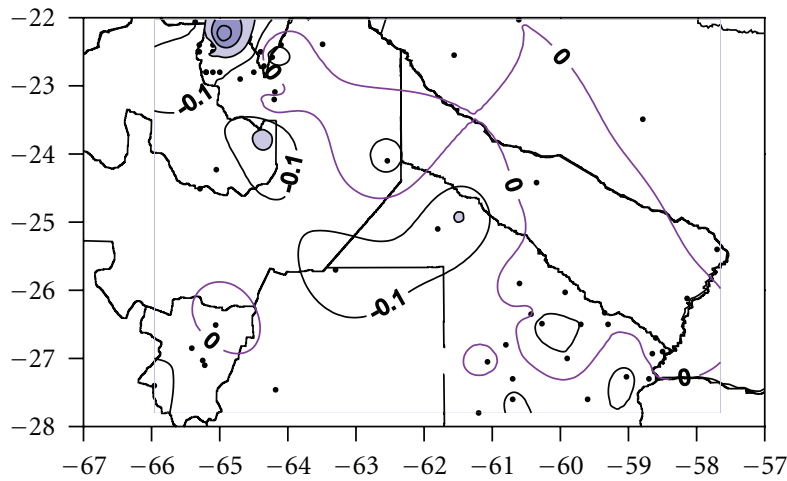

(h) SST1

Figure 5: Continued. 


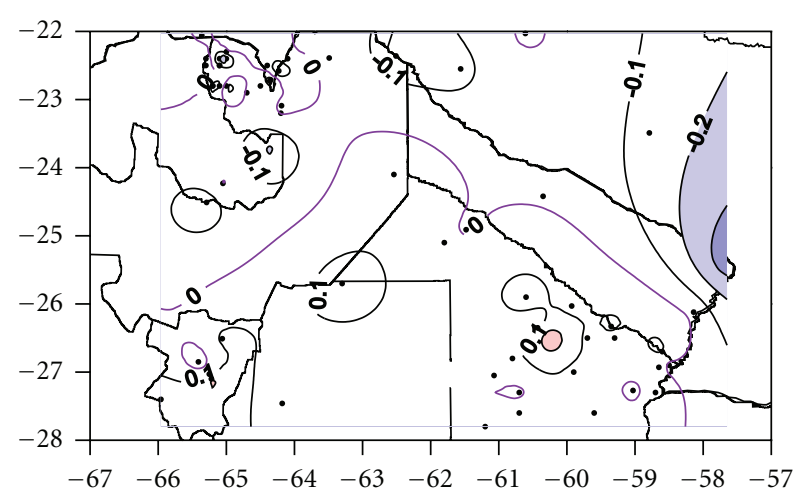

(i) SST2

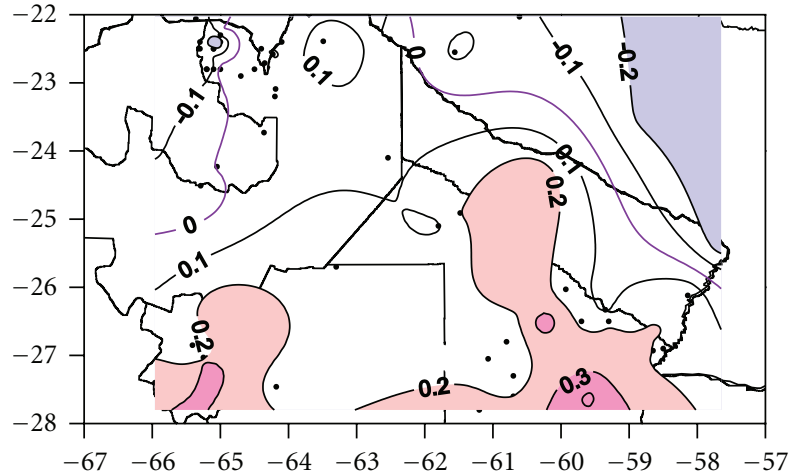

(j) SST3

FIgURE 5: Idem Figure 3 for Winter (JJA) rainfall.

\section{Results}

Figures 3-7 show the correlation fields between seasonal rainfall and all the defined indexes. Figure 3 shows simultaneous correlations between DJF rainfall and previously defined indexes. A positive significant correlation with DMI (Figure 3(b)) is present in a small area in the eastern of the study region, suggesting some influence of the DMI on summer rainfall. The south of the region is related to the position of the SAH (Figure 3(e)), indicating that rainfall is enhanced when the SAH is displaced towards the south. This implies that the low-level flow from the east is reinforced and so, more humid air enters the continent from the ocean. This effect is even greater if one considers that rainfall in the south of the area is also enhanced by high SST in the coast of southern Brazil, as it can be seen in the SST2 and SST3 correlation field (Figures 3(i) and 3(j), resp.). Another important factor is ENSO (Figure 3(g)); therefore, summer precipitation is enhanced in the east of the area when the warm phase of ENSO is present. This result agrees with some authors who studied the impacts of "El Niño" in South America [14-16].

Therefore, the influence of ENSO, SST2, and SST3 is present as it can be seen in the correlation fields (Figures 3(i), 3(j) and 3(g)) in Presidente Roque Saenz Peña (PRSP) station, located in the southern part of the study area $\left(26,5^{\circ} \mathrm{S} ; 60,27^{\circ} \mathrm{W}\right)$. A multiple linear regression calculated using a standard method for summer rainfall in such station using as predictors ENSO and SST2 was significant at the 95\% confidence level using a Fisher test and explained the $28,7 \%$ of the summer precipitation variance. It is important to notice that SST3 was not considered because it was highly correlated to SST2 $(0,62)$ and predictors must be independent. In Charadai station, located southeast of PRSP $\left(27,6^{\circ} \mathrm{S} ; 59,6^{\circ} \mathrm{W}\right)$ the effects of LATA and SST2 were significant (Figures 3(e) and 3(i)). The multiple regression derived with these two predictors was significant at the $95 \%$ confidence level and explained the $26,5 \%$ of summer rainfall variance. The stations mentioned in this section are detailed in Figure 1.
Figure 4 shows the correlation between the indexes and MAM precipitation. The main factors that enhanced rainfall are detailed hereinafter. Convection greater than normal in Central Brazil reinforces the northern flow in the northwestern of the area of study and thus precipitation (Figure 4(c)). Generally this pattern is observed in years with a delay in the end of the South America Monsoon [31]. Also, a cold phase of ENSO (Figure $4(\mathrm{~g})$ ) enhances rainfall in the west of the area. Autumn rainfall in Caimancito station, located in $\left(23,7^{\circ} \mathrm{S} ; 64,4^{\circ} \mathrm{W}\right)$ in the northwest of the study area, is influenced by both Central Brazil convection and ENSO (Figures 4(c) and 4(g)). The multiple regression using such both predictors explained the $15,6 \%$ of the autumn rainfall variance with the $95 \%$ confidence level.

In the southern and even central part of the area of study, rainfall is related to a more intense (Figure $4(\mathrm{~d})$ ) and western displacement of SAH (Figure 4(f)) and high SST in the southern Brazil and Argentina coasts (Figures 4(i) and $4(j))$, probably because these factors increase the humid air advection from the Atlantic ocean. These factors affect autumn rainfall in the south as it can be noted in PRSP station $\left(26,5^{\circ} \mathrm{S} ; 60,27^{\circ} \mathrm{W}\right)$ (Figures $4(\mathrm{~d}), 4(\mathrm{f})$, and $4(\mathrm{i})$ ). In effect, the multiple regressions using as predictors: IA, LONA and SST2, significant at the 95\% confidence level and explained the $27,6 \%$ of autumn rainfall variance.

Figure 5 shows the correlation between indexes and JJA rainfall. Some factors affecting winter precipitation will be detailed. As the air trajectory from the SAH is normally displaced to the west in winter, the presence of convection greater than normal in Central Brazil seems to reinforce rainfall in the east of the area of study (Figure 5(c)); a $\mathrm{SAH}$ displaced towards the south (Figure 5(e)) and east (Figure 5(f)) enhances rainfall in the northeast, and warm SST in Argentina and Uruguay coasts (Figure 5(j)) does it the same in the southern part of the study region. The multiple regression for winter rainfall in PRSP station using OLR and SST3 as predictors (the main factors that affect rainfall in PRSP station, Figures 5(c) and 5(j)) were significant at the $95 \%$ confidence level and explained the $25,4 \%$ of winter precipitation variance. 


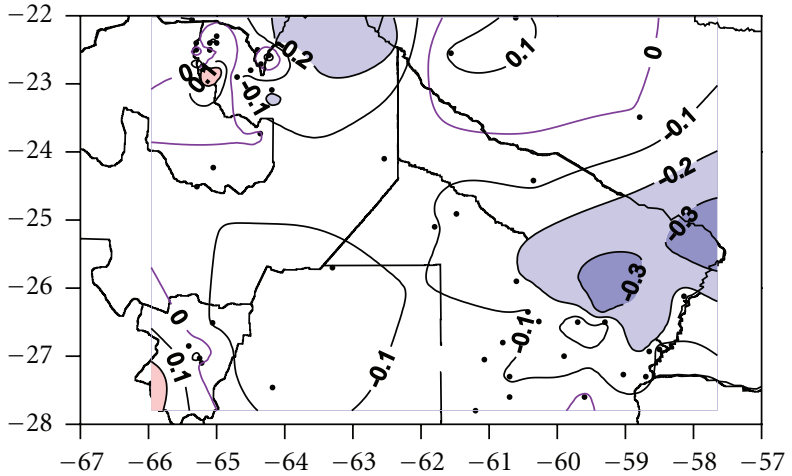

(a) $\mathrm{AAO}$

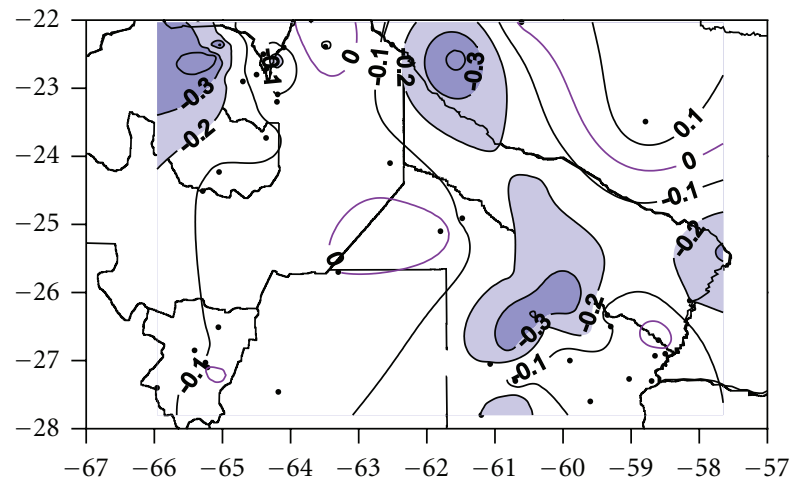

(c) OLR

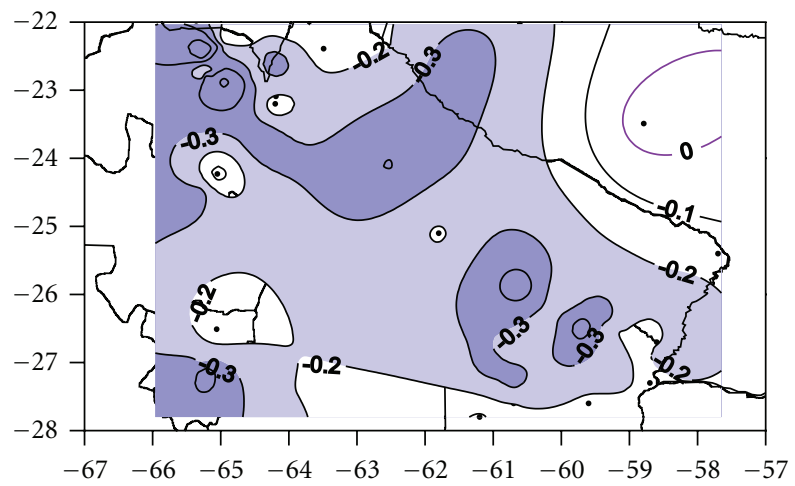

(e) LATA

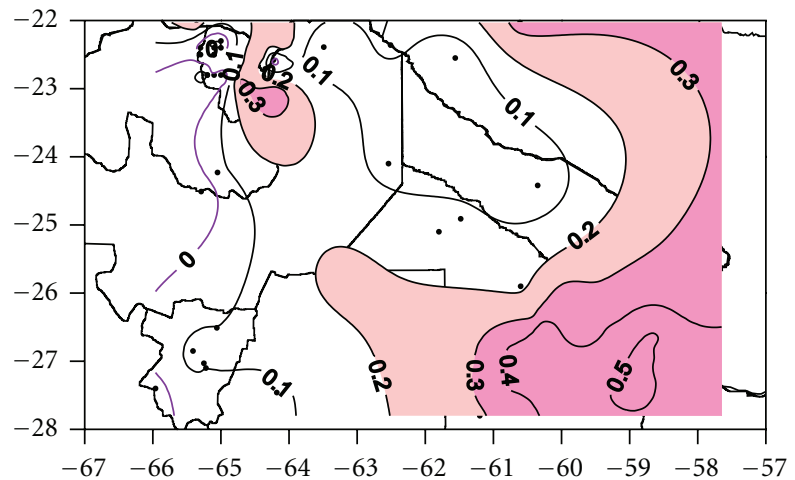

(g) ENSO

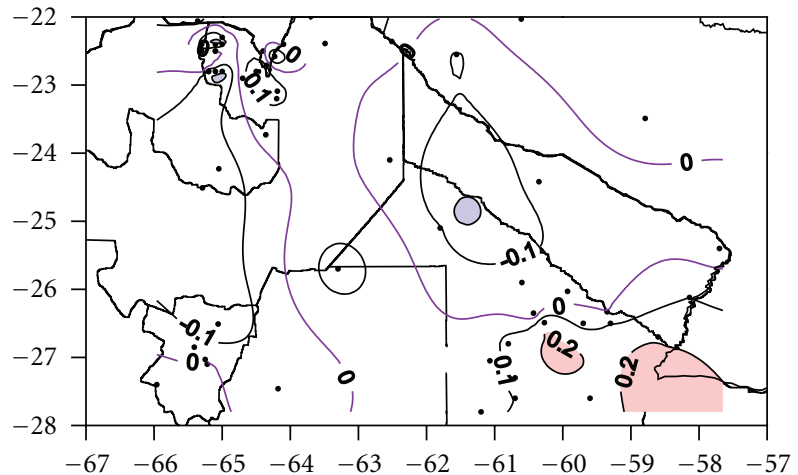

(b) DMI

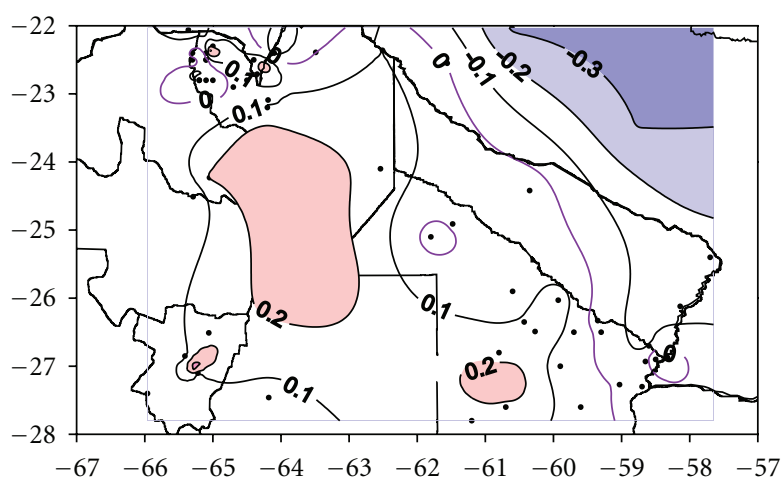

(d) IA

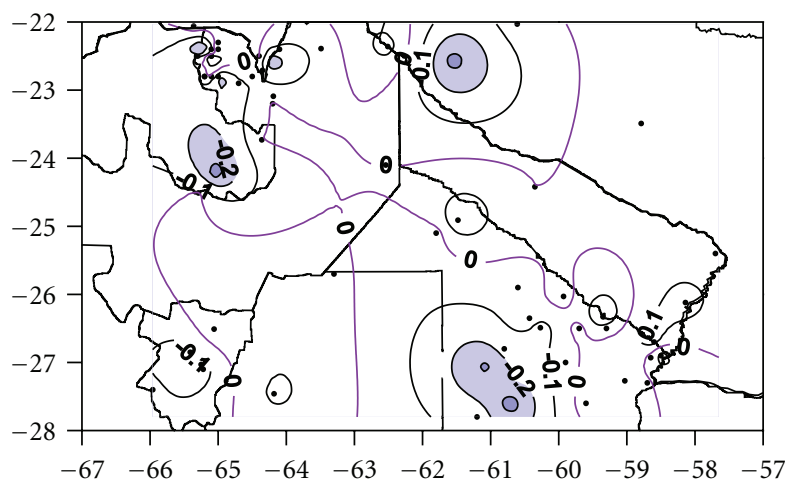

(f) LONA

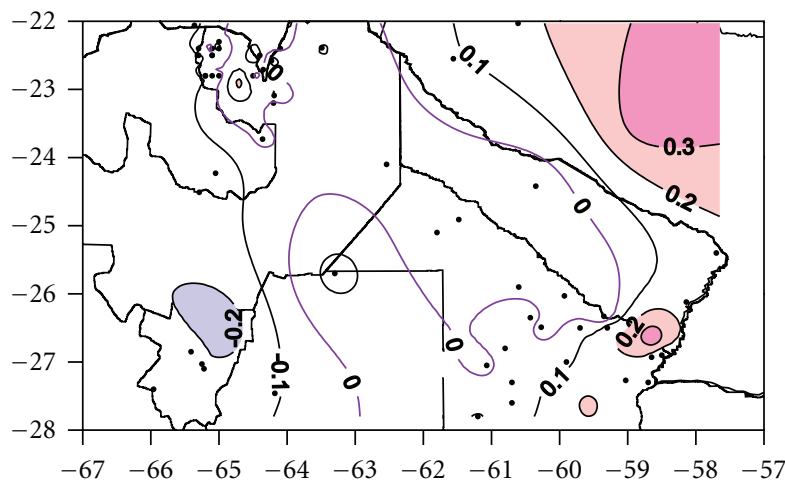

(h) SST1

FIgURE 6: Continued. 


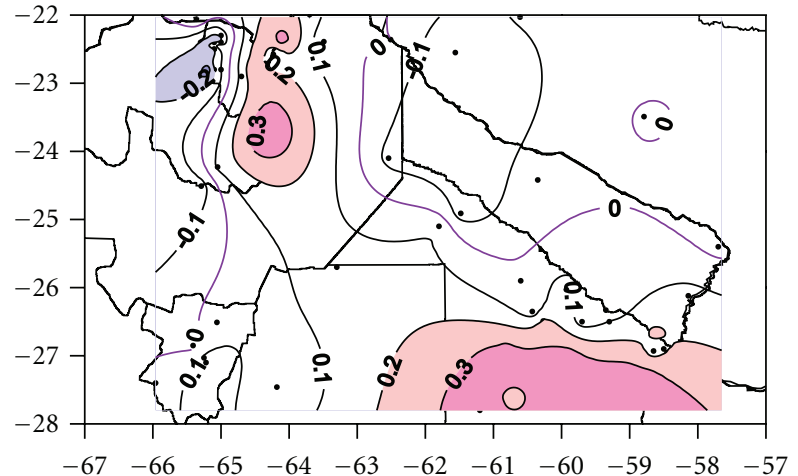

(i) SST2

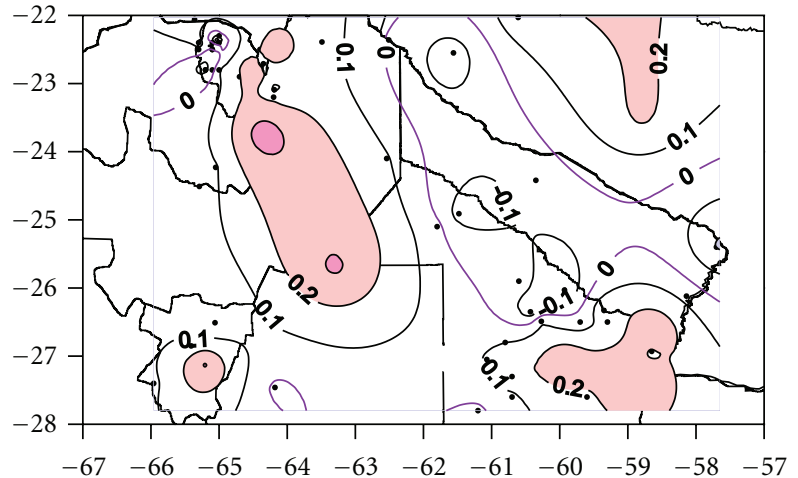

(j) SST3

FIgURE 6: Idem Figure 3 for Spring (SON) rainfall.

In the spring case (SON rainfall, Figure 6), precipitation is enhanced in the east when a negative phase of AAO is present (Figure 6(a)), as it was previously pointed out by Silvestri and Vera [22] and Reboita [23]. Another relevant factor is the increase of rainfall in the north and east when the convection is greater than normal in Central Brazil (Figure 6(c)), this result agrees with Gonzalez and Barros [29] who detected that an advanced South American Monsoon onset date causes more than normal spring rainfall in this area. A SAH displaced to the south derives in greater rainfall all over the area (Figure 6(e)), and this effect is reinforced by anomaly warm SST in Southern Brazil (Figure 6(i)) which determines more rainfall in the southeast. Also, anomaly warm SST between $10^{\circ} \mathrm{S}$ and $20^{\circ} \mathrm{S}$ (Figure 6(h)) produces more precipitation in the northeast. The last factor is the relevant effect of ENSO: spring rainfall in the east is enhanced in ENSO warm phase (Figure 6(g)), as it was observed by other authors [15]. Spring rainfall in PRSP station, in the south of the study area is influenced by LATA (Figure 6(e)), ENSO (Figure 6(g)) and y SST2 (Figure 6(i)). However, the multiple regressions using only the predictors LATA and ENSO resulted significantly at the $95 \%$ confidence level and explained the $28,3 \%$ of the spring rainfall, indicating that the effect of SST2 is less relevant than the influence of both, LATA and ENSO. In the northwest part of the study region some factors affects spring rainfall: LATA, ENSO, OLR (Figures 6(e), 6(g), and 6(c)). But the regression obtained using only ENSO was significant at the $95 \%$ confidence level in Oran station $\left(23,1^{\circ} \mathrm{S} ; 64,2^{\circ} \mathrm{W}\right)$, indicating that ENSO is the most relevant phenomenon that influences spring rainfall in that area. In the northeast of the study area, factors that influence spring rainfall are AAO y ENSO (Figures 6(a) and 6(g)). Therefore, the multiple regression in El Colorado station $\left(26,3^{\circ} \mathrm{S} ; 59,3^{\circ} \mathrm{W}\right)$ was significant at the $95 \%$ confidence level, using both predictors explaining the $19,2 \%$ of spring rainfall.

When the accumulated annual rainfall is considered (Figure 7), all the signals decrease because of the opposite responses in different seasons. However, convection intensified in Central Brazil seems to enhance rainfall in the north and east (Figure 7(c)); a SAH displaced to the west reinforce rainfall in the east (Figure 7(f)) and warm SST in Southern Brazil, Uruguay, and Argentina (Figures 7(i) and 7(j)) does it the same in the southeast region.

\section{Cases of Study}

To illustrate the incidence of the described patterns over rainfall, the cases of SON 1999 and SON 1994 will be detailed in this section. In those cases, some of the factors described above combined and determined an extreme rainfall situation. The drought occurred in 1999 spring produced substantial losses mainly caused by the cotton crops, great slaughter of animals, and the stack of the Paraguay and Parana rivers. Figure 8 shows the anomaly precipitation field in SON 1999. Most of the area has less rainfall than normal, except for the southwestern region, with a relevant zonal gradient. Table 1 shows the index values for SON 1999 (central panel). Some factors contributed to produce rainfall below normal in the east of the area: ENSO, SST2, and SST3 negative anomalies and AAO, IA and OLR positive anomalies. LATA anomaly is negative in SON 1999 and this fact can be associated with the positive rainfall anomaly in the west. Therefore, the maximum LATA correlation signal is located in western of the area of study (see Figure 6).

On the other hand, 1994 spring is an example of relevant flooding. Figure 9 shows rainfall anomaly field for SON 1994. In this case, the area under study is really dominated by positive anomalies rainfall in most part of the area, except for the central region. The principal factors that influenced rainfall in the east in SON 1994 were ENSO, SST2, and SST3 warm anomalies and OLR and IA negative anomalies (see Table 1, right panel).

\section{Conclusions}

Results show that the factors which affect precipitation highly depend on the season and the region. A SAH displaced towards the south and higher than normal SST in the coast between $20^{\circ} \mathrm{S}$ and $40^{\circ} \mathrm{S}$ seem to enhance rainfall all over 


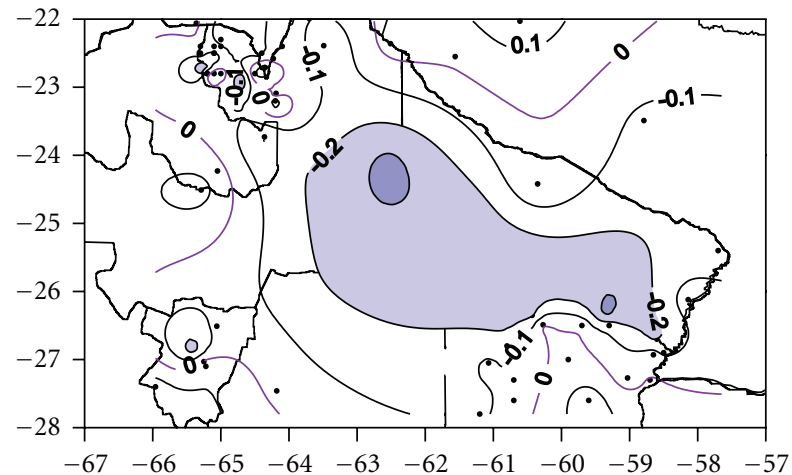

(a) $\mathrm{AAO}$

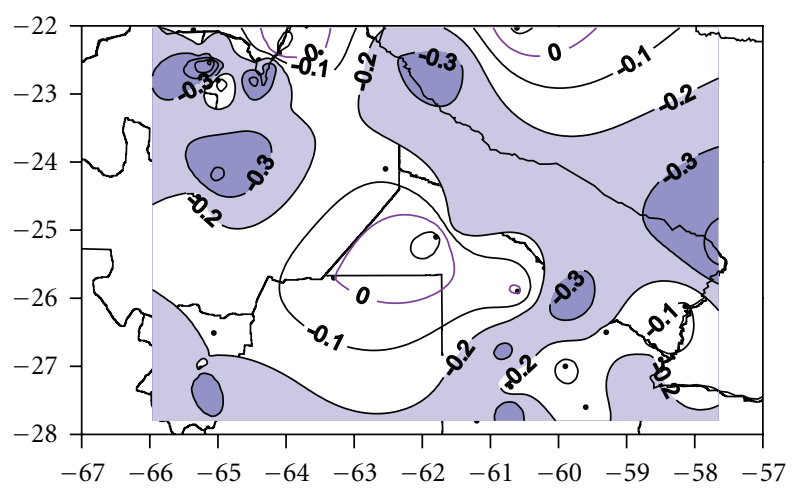

(c) CLR

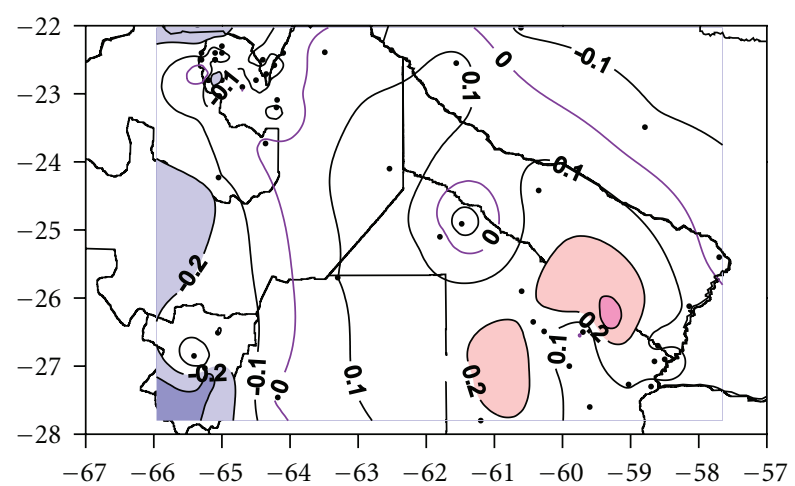

(e) LATA

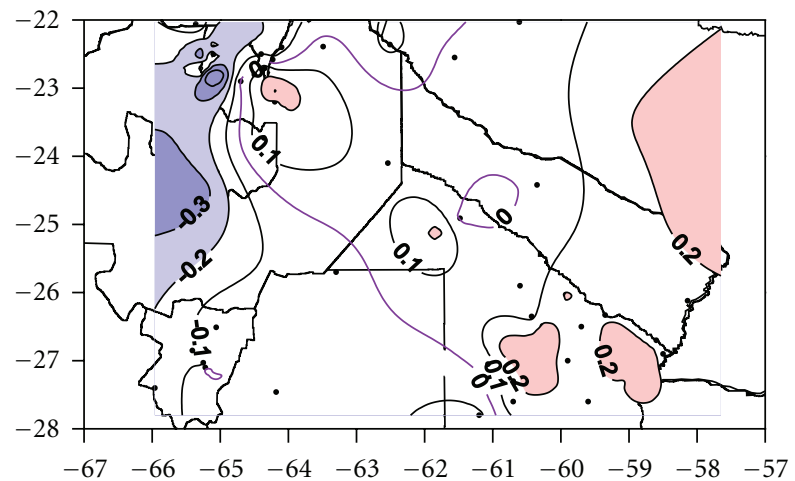

(g) ENSO

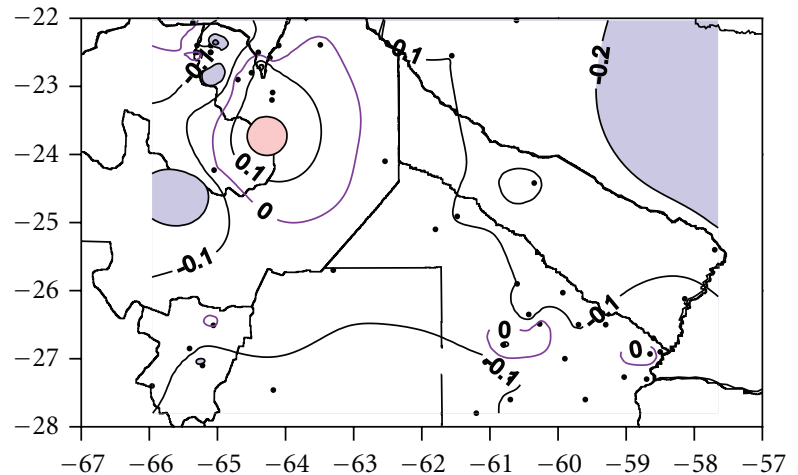

(b) DMI

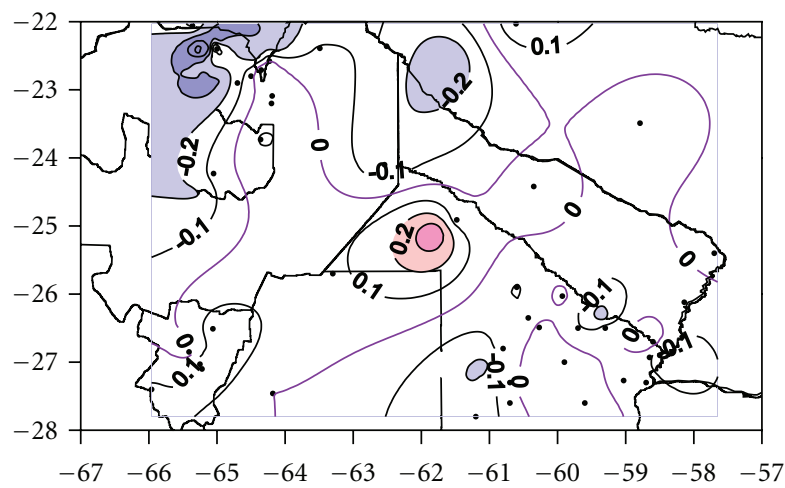

(d) IA

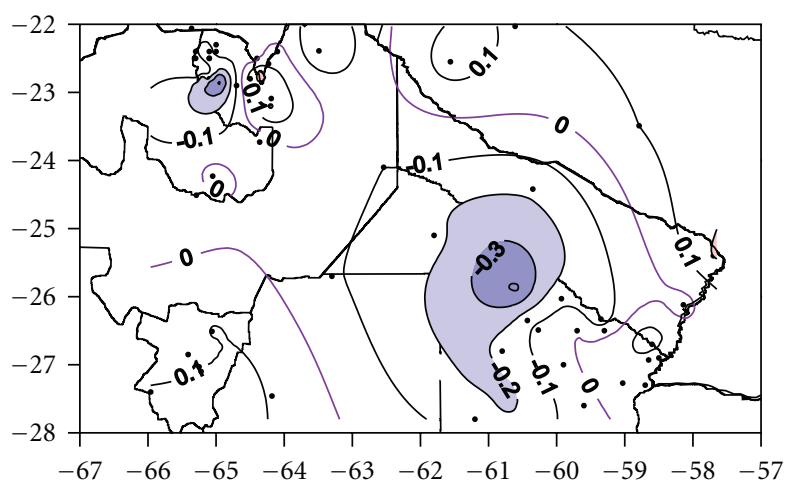

(f) LONA

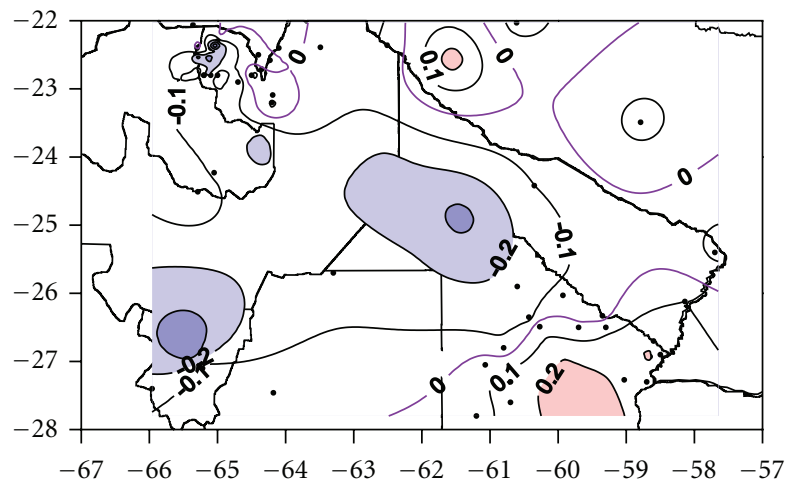

(h) SST1

Figure 7: Continued. 


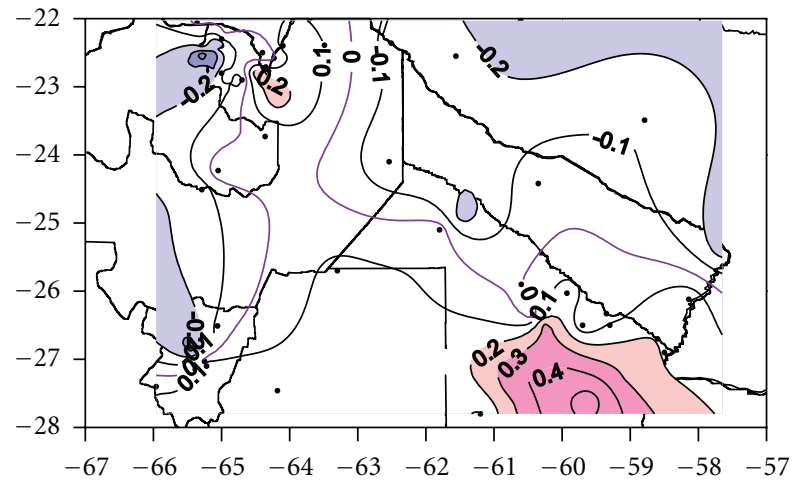

(i) SST2

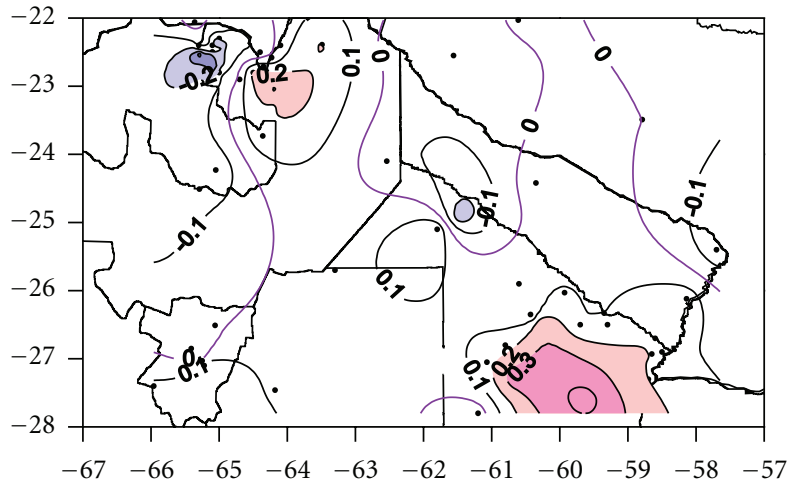

(j) SST3

FIgURe 7: Idem Figure 3 for Annual rainfall.

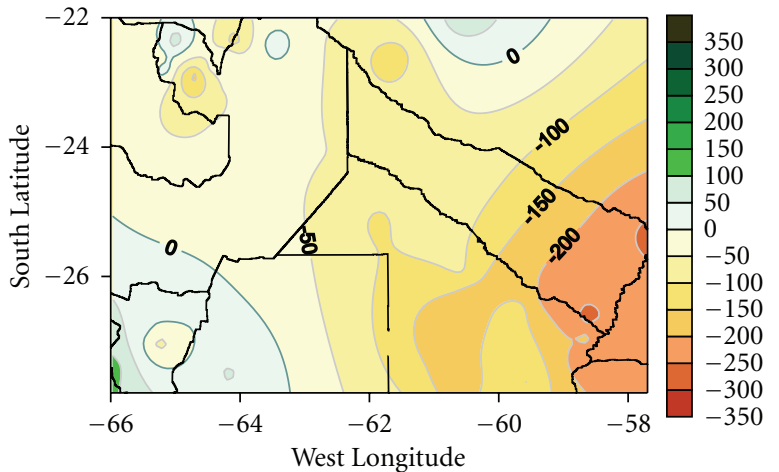

FIgURE 8: Rainfall anomaly in SON 1999. Anomalies are calculated from 1961-2010 seasonal mean.

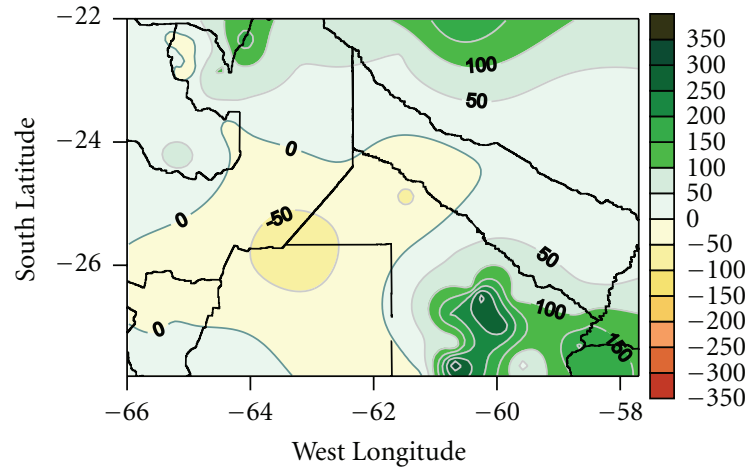

FIGURE 9: Rainfall anomaly in SON 1994. Anomalies are calculated from 1961-2010 seasonal mean.

the year, especially in the south of the area, although in spring their effect involves the whole region. Spring and summer rainfall are reinforced in the east when the warm phase of ENSO is present meanwhile La Niña increases precipitation in the northwest, especially in autumn. A higher than normal convection in Central Brazil reinforces rainfall in transition seasons (spring and autumn) probably related to an advanced onset (spring) and a delayed end (autumn) of the South American Monsoon, especially in the north. Also, a relevant convection anomaly in winter produces an anomalous northern flow which can enhance precipitation over the whole region. Furthermore, a negative phase of SAM derive in spring rainfall increased in the east of study region. This is a preliminary study to identify the main circulation patterns which are related to precipitation. Based on this research, dominant circulation patterns would be helpful to forecast seasonal precipitation in Argentinean Chaco region. In the future, the authors will investigate the relative contribution of each forcing to seasonal rainfall but that objective is beyond the scope of this paper.

\section{Acknowledgments}

Rainfall data were provided by the Meteorology and Hidrology Direction of Paraguay (DMH), the National Meteorological Service of Argentina (SMN), the Secretary of Hydrology of Argentina (SRH) the Provincial Water Administration of Chaco (APA) and the Regional Commission of Bermejo River (COREBE). This research was supported by UBACyT 2010-2012 CC02, UBACyT 2011-2014 01/Y128, CONICET PIP 112-200801-00195, and CLARIS LPB.

\section{References}

[1] M. S. Reboita, M. A. Gan, R. P. Da Rocha, and T. Ambrizzi, "Regimes de precipitacao na America do sul," Revista Brasilera De Meteorologia, vol. 25, no. 2, pp. 185-204, 2010.

[2] M. H. González and A. M. Murgida, "Seasonal Summer rainfall prediction in Bermejo River Basin in Argentina," in Climate Variability - Some Aspects, Challenges and Prospects, A. Hannachi, Ed., chapter 7, pp. 141-160, Department of Meteorology, University of Reading, INTech, Reading, UK, 2012.

[3] M. H. Gonzalez, D. Dominguez, and M. N. Nuñez, "Long term and interannual rainfall variability in argentinean Chaco plain region," in Rainfall: Behavior, Forecasting and Distribution, J. Schlapa, Ed., Nova Science Publishers, 2012.

[4] L. Ferreira, C. Saulo, and M. Selucchi, "Características de la depresión del noroeste argentino en el período 1997-2003: 
criterios de selección y análisis estadístico," Meteorologica, vol. 35 , no. 1, pp. 17-25, 2010.

[5] J. D. Lenters and K. H. Cook, "On the origin of the Bolivian high and related circulation features of the South American climate," Journal of the Atmospheric Sciences, vol. 54, no. 5, pp. 656-677, 1997.

[6] M. Wang and J. Paegle, "Impact of analysis uncertainty upon regional atmospheric moisture flux," Journal of Geophysical Research D, vol. 101, no. 3, pp. 7291-7303, 1996.

[7] V. Barros, M. Doyle, M. H. Gonzalez, I. Camilloni, R. Bejarán, and M. Caffera, "Revision of the south american monsoon system and climate in subtropical South America south of 20 S," Meteorologica, vol. 27, pp. 33-58, 2002.

[8] C. Vera, W. Higgins, J. Amador et al., "Toward a unified view of the American monsoon systems," Journal of Climate, vol. 19, no. 20, pp. 4977-5000, 2006.

[9] V. R. Barros, M. E. Doyle, and I. A. Camilloni, "Precipitation trends in southeastern South America: relationship with ENSO phases and with low-level circulation," Theoretical and Applied Climatology, vol. 93, no. 1-2, pp. 19-33, 2008.

[10] M. H. Gonzalez and O. K. Flores, "Análisis de la precipitación en la llanura chaqueña argentina y su relación con el comportamiento de la circulación atmosférica y las temperaturas de la superficie del mar," Meteorologica, vol. 35, no. 2, pp. 53-66, 2010.

[11] J. W. Kidson, "Principal modes of Southern Hemisphere lowfrequency variability obtained from NCEP-NCAR reanalyses," Journal of Climate, vol. 12, no. 9, pp. 2808-2830, 1999.

[12] K. C. Mo, "Relationships between low-frequency variability in the Southern Hemisphere and sea surface temperature anomalies," Journal of Climate, vol. 13, no. 20, pp. 3599-3610, 2000.

[13] J. N. Paegle and K. C. Mo, "Linkages between summer rainfall variability over South America and sea surface temperature anomalies," Journal of Climate, vol. 15, no. 12, pp. 1389-1407, 2002.

[14] C. Ropelewski and M. Halpert, "Global and Regional scale precipitation patterns associated with El Niño," Monthly Weather Review, vol. 110, pp. 1606-1626, 1987.

[15] A. Grimm, V. Barros, and M. Doyle, "Climate variability in Southern South America associated with El Niño and La Niña events," Journal of Climate, vol. 13, pp. 35-58, 2002.

[16] C. Vera, G. Silvestri, V. Barros, and A. Carril, "Differences in El Niño response in Southern Hemisphere," Journal of Climate, vol. 17, no. 9, pp. 1741-1753, 2004.

[17] N. H. Saji, B. N. Goswami, P. N. Vinayachandran, and T. Yamagata, "A dipole mode in the tropical Indian ocean," Nature, vol. 401, no. 6751, pp. 360-363, 1999.

[18] S. Chan, S. K. Behera, and T. Yamagata, "Indian Ocean Dipole influence on South American rainfall," Geophysical Research Letter, vol. 35, Article ID L14S12, 5 pages, 2008.

[19] N. Liu, H. X. Chen, and L. G. Lü, "Teleconnection of IOD signal in the upper troposphere over southern high latitudes," Journal of Oceanography, vol. 63, no. 1, pp. 155-157, 2007.

[20] B. J. Hoskins and D. J. Karoly, "The steady linear response of a spherical atmosphere to thermal and orographic forcing.," Journal of the Atmospheric Sciences, vol. 38, no. 6, pp. 11791196, 1981.

[21] D. W. J. Thompson and J. M. Wallace, "Annular modes in the extratropical circulation. Part I: month-to-month variability," Journal of Climate, vol. 13, no. 5, pp. 1000-1016, 2000.

[22] G. E. Silvestri and C. S. Vera, "Antarctic Oscillation signal on precipitation anomalies over southeastern South America," Geophysical Research Letters, vol. 30, no. 21, article 2115, 2003.
[23] M. S. Reboita, T. Ambrizzi, and R. Da Rocha, "Relationship between the Southern Annular Mode and Southers Hemisphere atmospheric systems," Revista Brasilera de Meteorologia, vol. 24, no. 1, pp. 48-55, 2009.

[24] X. Zheng and C. S. Frederiksen, "A study of predictable patterns for seasonal forecasting of New Zealand rainfall," Journal of Climate, vol. 19, no. 13, pp. 3320-3333, 2006.

[25] C. Reason and M. Rouault, "Links between the Antartic Oscillation and winter rainfall over western South Africa," Geophysical Research Letters, vol. 32, Article ID L07705, 4 pages, 2005.

[26] C. Vera, W. Higgins, J. Amador et al., "Toward a unified view of the American monsoon systems," Journal of Climate, vol. 19, no. 20, pp. 4977-5000, 2006.

[27] M. E. Doyle and V. R. Barros, "Midsummer low-level circulation and precipitation in subtropical South America and related sea surface temperature anomalies in the South Atlantic," Journal of Climate, vol. 15, no. 23, pp. 3394-3410, 2002.

[28] S. Nan and J. Li, "The relationship between summer precipitation in the Yangtse River Valley and the previous Southern hemisphere Annular Mode," Geophysical Research Letters, vol. 30 , no. 24, article 2266, 2003.

[29] M. H. Gonzalez and V. Barros, "The relation between tropical convection in South America and the end of the dry period in subtropical Argentina," International Journal of Climatology, vol. 18, no. 15, pp. 1671-1687, 1998.

[30] E. Kalnay, M. Kanamitsu, R. Kistler et al., "The NCEP/NCAR 40-year reanalysis project," Bulletin of the American Meteorological Society, vol. 77, no. 3, pp. 437-471, 1996.

[31] M. González and V. Barros, "On the forecast of the onset and end of the convective season in the Amazon," Theoretical and Applied Climatology, vol. 73, no. 3-4, pp. 169-187, 2002. 

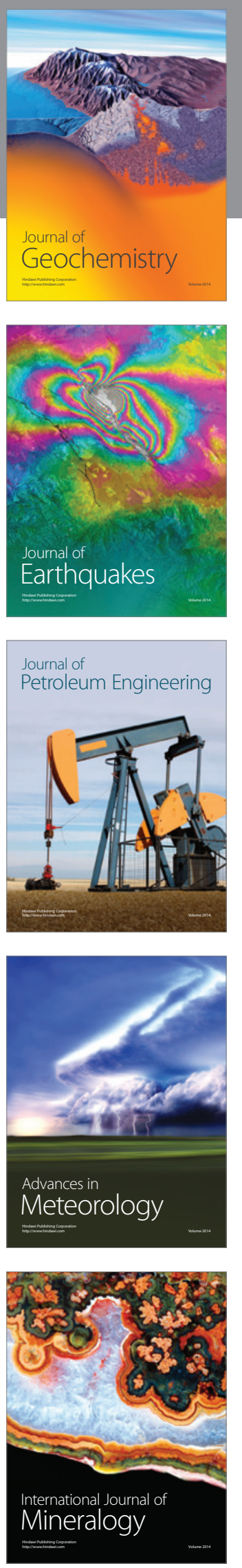
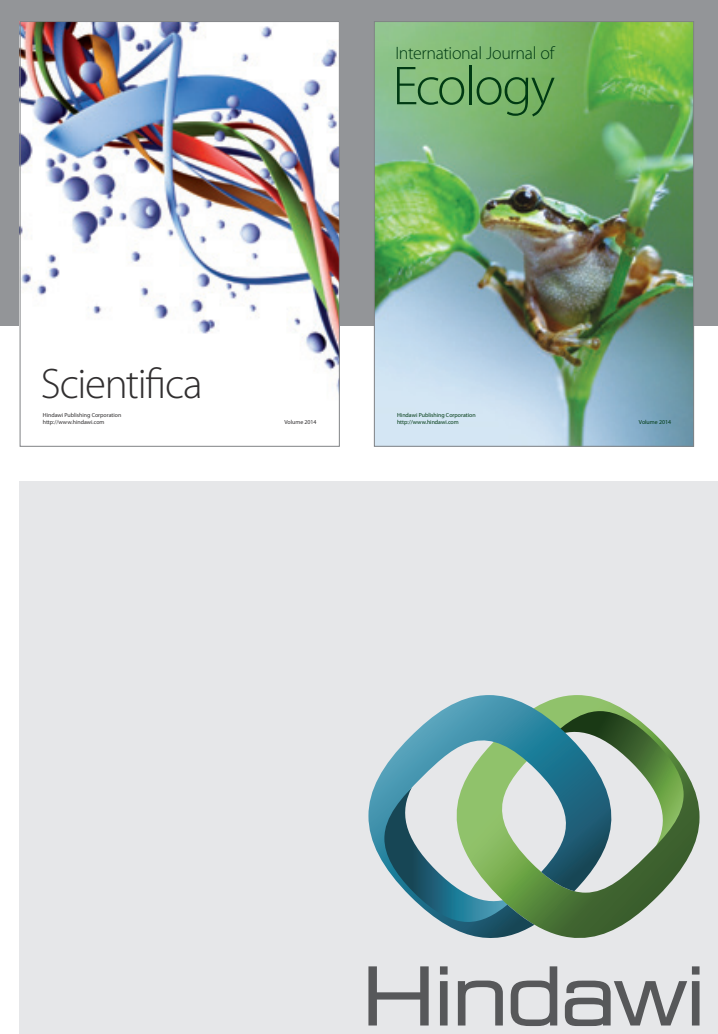

Submit your manuscripts at http://www.hindawi.com
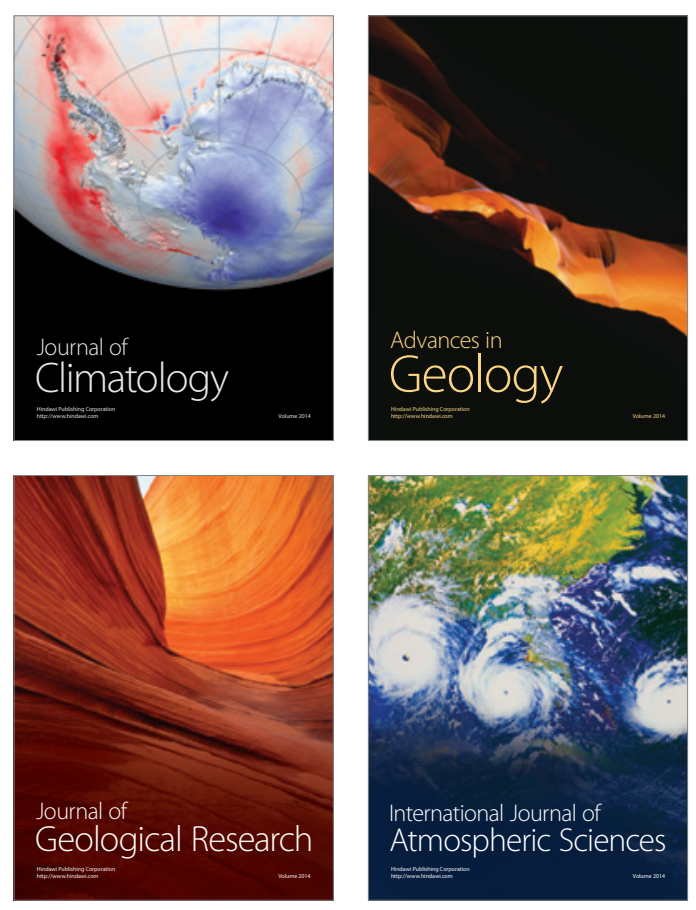
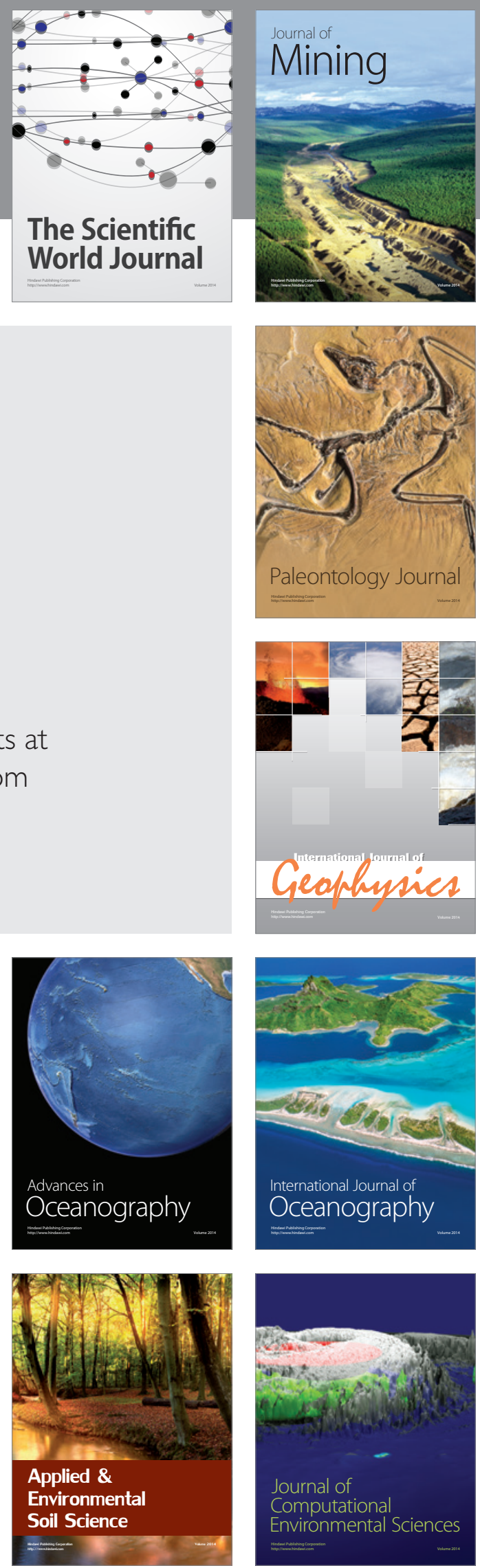